Review

\title{
Sorghum's Whole-Plant Transcriptome and Proteome Responses to Drought Stress: A Review
}

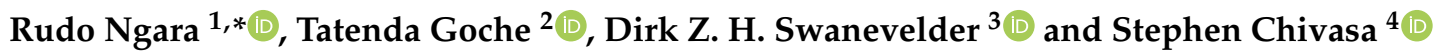 \\ 1 Department of Plant Sciences, University of the Free State, Qwaqwa Campus, \\ Phuthadithjaba 9866, South Africa \\ 2 Department of Crop Sciences, Gwanda State University, Epoch Mine Campus, Filabusi, Zimbabwe; \\ tatendagoche@gmail.com \\ 3 Agricultural Research Council's Biotechnology Platform, ARC Onderstepoort Campus, \\ Onderstepoort 0110, South Africa; SwanevelderD@arc.agric.za \\ 4 Department of Biosciences, Durham University, South Road, Durham DH1 3LE, UK; \\ stephen.chivasa@durham.ac.uk \\ * Correspondence: NgaraR@ufs.ac.za; Tel.: +27-(0)58-718-5332
}

check for

updates

Citation: Ngara, R.; Goche, T.; Swanevelder, D.Z.H.; Chivasa, S. Sorghum's Whole-Plant

Transcriptome and Proteome Responses to Drought Stress: A Review. Life 2021, 11, 704. https:// doi.org/10.3390/life11070704

Academic Editors: Claudius Marondedze, Marco Chiapello and Nino Nikolovski

Received: 18 June 2021

Accepted: 15 July 2021

Published: 17 July 2021

Publisher's Note: MDPI stays neutral with regard to jurisdictional claims in published maps and institutional affiliations.

Copyright: (c) 2021 by the authors. Licensee MDPI, Basel, Switzerland. This article is an open access article distributed under the terms and conditions of the Creative Commons Attribution (CC BY) license (https:// creativecommons.org/licenses/by/ $4.0 /)$.

\begin{abstract}
Sorghum is a cereal crop with key agronomic traits of drought and heat stress tolerance, making it an ideal food and industrial commodity for hotter and more arid climates. These stress tolerances also present a useful scientific resource for studying the molecular basis for environmental resilience. Here we provide an extensive review of current transcriptome and proteome works conducted with laboratory, greenhouse, or field-grown sorghum plants exposed to drought, osmotic stress, or treated with the drought stress-regulatory phytohormone, abscisic acid. Large datasets from these studies reveal changes in gene/protein expression across diverse signaling and metabolic pathways. Together, the emerging patterns from these datasets reveal that the overall functional classes of stress-responsive genes/proteins within sorghum are similar to those observed in equivalent studies of other drought-sensitive model species. This highlights a monumental challenge of distinguishing key regulatory genes/proteins, with a primary role in sorghum adaptation to drought, from genes/proteins that change in expression because of stress. Finally, we discuss possible options for taking the research forward. Successful exploitation of sorghum research for implementation in other crops may be critical in establishing climate-resilient agriculture for future food security.
\end{abstract}

Keywords: sorghum; drought stress; whole-plant responses; systems biology; transcriptomics; proteomics; differentially expressed genes; differentially accumulated proteins

\section{Introduction}

Sorghum (Sorghum bicolor) is the world's 5th most important cereal in terms of area harvested and yield [1]. Together with pearl millet (Pennisetum glaucum) [2], sorghum grows well in hot and dry environments less suitable for other major cereals, such as maize (Zea mays) and rice (Oryza sativa) [3,4]. The sorghum plant has many uses, with its grain used as a source of food and feed, while stalks provide raw materials for building, broom-making, and biofuel production [3-5]. Sorghum germplasm is genetically diverse, with large active and base collections of landraces, improved breeding lines/cultivars, and wild relatives being maintained across several genebanks worldwide [6-8]. This rich gene pool provides essential genetic variation required for sorghum research, breeding, and crop improvement programs $[8,9]$.

Despite sorghum's economic importance [5] and rich genetic diversity [3,6-8], its genetic potential is relatively underused compared to other major cereals [2]. Sorghum production is also constrained by several biotic and abiotic stresses [3,4,8,10]. Among the latter, drought and heat stresses can significantly reduce the yield of some sorghum varieties, especially in rain-fed agricultural systems [11,12]. Heat and drought spells are 
also predicted to increase in occurrence with global warming [13,14], further constraining crop productivity of subsistence farmers in drought-prone areas. In such communities, adequate food provision will become even more challenging due to a combination of socio-economic factors, unpredictable climates, and the use of inferior crop varieties [12]. Additionally, with the ever-increasing population, food insecurity is now a global concern, and agricultural scientists are looking at underused but climate-resilient crops and varieties, including those of sorghum, for cultivation in marginal lands [2].

Sorghum is generally regarded as being drought-resilient; however, the degree of tolerance varies between species, genotypes/accessions, the prevailing environmental conditions, and their complex interactions [3,4]. Plants are therefore still vulnerable to drought stress at some point during growth $[10,15]$, with exposure and different susceptibilities to moisture stress at these developmental stages potentially disrupting seed germination, plant establishment, growth, flowering, and/or grain filling processes, ultimately reducing grain size and yield [10,15-17]. In extreme cases, plant death and complete crop failure may occur $[10,17]$. However, the varying degrees of accession tolerances result in some capable of withstanding soil moisture stress during the pre-flowering stage, while others provide tolerance in the post-flowering growth stages $[16,18,19]$. Pre-flowering drought-tolerant lines maintain normal panicle development when exposed to water deficits during the pre-flowering phase [16]. In contrast, post-flowering drought-tolerant lines are associated with the stay-green trait, retaining high chlorophyll content and photosynthetic activity after anthesis during terminal drought [16,20-22]. Such genetic diversity is invaluable for environment-specific crop breeding programs.

Apart from this wide gene pool, the sorghum genome has been sequenced [23] and is available on online databases such as Phytozome [24] and the National Center for Biotechnology Information (NCBI) [25] (Table 1). In general, the availability of crop genome sequences is a major milestone in agricultural biotechnology, which enables the identification of genes associated with important agronomic traits [26-28]. Its small genome size $( \pm 730 \mathrm{Mb})$ make sorghum an ideal model plant for comparative functional genomics in grasses $[23,29,30]$, for understanding the $C_{4}$ photosynthesis pathway, and the drought tolerance trait $[23,26]$. To aid the scientific community in this endeavor, some computational tools have been developed to support "omics" (genomics, transcriptomics, proteomics, metabolomics and bioinformatics) research of this crop (Table 1). Consequently, just over a decade after the release of the first draft sorghum genome sequence [23], research interest in "omics" studies of sorghum in response to abiotic stresses is steadily increasing (Figure 1). Therefore, we review drought transcriptomics and proteomics studies of sorghum wholeplant systems and highlight target genes and proteins for further functional studies prior to their application in crop breeding programs.

Table 1. Databases and computational resources/tools supporting sorghum "omics" research.

\begin{tabular}{llll}
\hline Database & Website ${ }^{*}$ & Features & References \\
\hline Genomic resources/tools & & & \\
\hline NCBI & http://ncbi.nlm.nih.gov & Plant genomics resource & [25] \\
\hline Phytozome & http://phytozome.jgi.doe.gov & Plant genomics resource & [24] \\
\hline Gramene & https://www.gramene.org & Grass genomics resource & [31] \\
\hline GreenPhylDB & http://www.greenphyl.org & $\begin{array}{l}\text { Comparative and functional genomics } \\
\text { in plants }\end{array}$ \\
\hline PGSB PlantsDB & $\begin{array}{l}\text { http://pgsb.helmholtz-muenchen. } \\
\text { de/plant/plantsdb.jsp }\end{array}$ & Comparative genomics in plants \\
\hline PlantGDB & http://www.plantgdb.org & Tools and resources for plant genomics
\end{tabular}


Table 1. Cont.

\begin{tabular}{|c|c|c|c|}
\hline Database & Website * & Features & References \\
\hline \multicolumn{4}{|l|}{ Genomic resources/tools } \\
\hline SorghumFDB & $\begin{array}{l}\text { http://structuralbiology.cau.edu.cn/ } \\
\text { sorghum/index.html }\end{array}$ & $\begin{array}{l}\text { Sorghum functional genomics with } \\
\text { network analysis }\end{array}$ & [35] \\
\hline SorGSD & http://sorgsd.big.ac.cn & Sorghum SNP data & [36] \\
\hline DNApod & http://tga.nig.ac.jp/dnapod & $\begin{array}{l}\text { Genome-wide DNA polymorphism } \\
\text { datasets of plants }\end{array}$ & {$[37]$} \\
\hline \multicolumn{4}{|l|}{ Transcriptomic resources } \\
\hline Grassius & https://grassius.org/links.php & $\begin{array}{l}\text { Grass transcription factors and } \\
\text { gene promoters }\end{array}$ & {$[38]$} \\
\hline GreenCircRNA & http://greencirc.cn & Plant circular RNAs (circRNAs) & [39] \\
\hline KAAS & www.genome.jp/tools/kaas/ & $\begin{array}{l}\text { Pathway enrichment analyses of } \\
\text { transcripts to classify spatial and } \\
\text { temporal pathways }\end{array}$ & {$[40]$} \\
\hline miRbase & http://www.mirbase.org & Plant microRNA (miRNA) data & [41] \\
\hline $\begin{array}{l}\text { Morokoshi } \\
\text { transcriptome database }\end{array}$ & $\begin{array}{l}\text { http://matsui-lab.riken.jp/morokoshi/ } \\
\text { Home.html }\end{array}$ & Sorghum transcriptome data & {$[42]$} \\
\hline PlantTFDB & http://planttfdb.gao-lab.org/index.php & Plant transcription factors & [43] \\
\hline PSRN & http://syslab5.nchu.edu.tw & $\begin{array}{l}\text { Plant stress-specific } \\
\text { transcriptome data }\end{array}$ & {$[44]$} \\
\hline psRNATarget & http:/ / plantgrn.noble.org/psRNATarget/ & $\begin{array}{l}\text { Potential miRNA sorghum target } \\
\text { predictions }\end{array}$ & {$[45]$} \\
\hline PtRFdb & http:/ / www.nipgr.ac.in & $\begin{array}{l}\text { Plant transfer RNA-derived } \\
\text { fragments (tRFs) data }\end{array}$ & [46] \\
\hline $\begin{array}{l}\text { psRobot; Plant small RNA } \\
\text { analysis toolbox }\end{array}$ & http://omicslab.genetics.ac.cn/psRobot/ & $\begin{array}{l}\text { Potential miRNA sorghum } \\
\text { target predictions }\end{array}$ & {$[47]$} \\
\hline UEA sRNA workbench & http:/ / srna-workbench.cmp.uea.ac.uk & Various smallRNA (sRNA) tools & [48] \\
\hline \multicolumn{4}{|l|}{ Proteomic resources } \\
\hline CropPal & https://crop-pal.org & Protein subcellular location & [49] \\
\hline ProtAnnDB & $\begin{array}{l}\text { http://www.polebio.lrsv.ups-tlse.fr/ } \\
\text { ProtAnnDB/ }\end{array}$ & Protein annotation & {$[50]$} \\
\hline ExPASy & https://www.expasy.org/ & $\begin{array}{l}\text { Bioinformatics resources for } \\
\text { proteomics }\end{array}$ & [51] \\
\hline Uniprot & https://www.uniprot.org & $\begin{array}{l}\text { Protein sequence and } \\
\text { functional information }\end{array}$ & [52] \\
\hline \multicolumn{4}{|l|}{$\begin{array}{l}\text { Gene ontology/ } \\
\text { metabolic pathways }\end{array}$} \\
\hline AgriGo & http:/ / bioinfo.cau.edu.cn/agriGO/ & $\begin{array}{l}\text { Gene ontology of plant and } \\
\text { agricultural species }\end{array}$ & [53] \\
\hline KEGG & https://www.genome.jp/kegg/ & Gene functional information & {$[54]$} \\
\hline SorghumCyc & $\begin{array}{l}\text { http://pathway.gramene.org/gramene/ } \\
\text { sorghumcyc.shtml }\end{array}$ & Metabolic pathways in sorghum & {$[31]$} \\
\hline
\end{tabular}

\footnotetext{
* Accessed on or before 18 July 2021.
} 


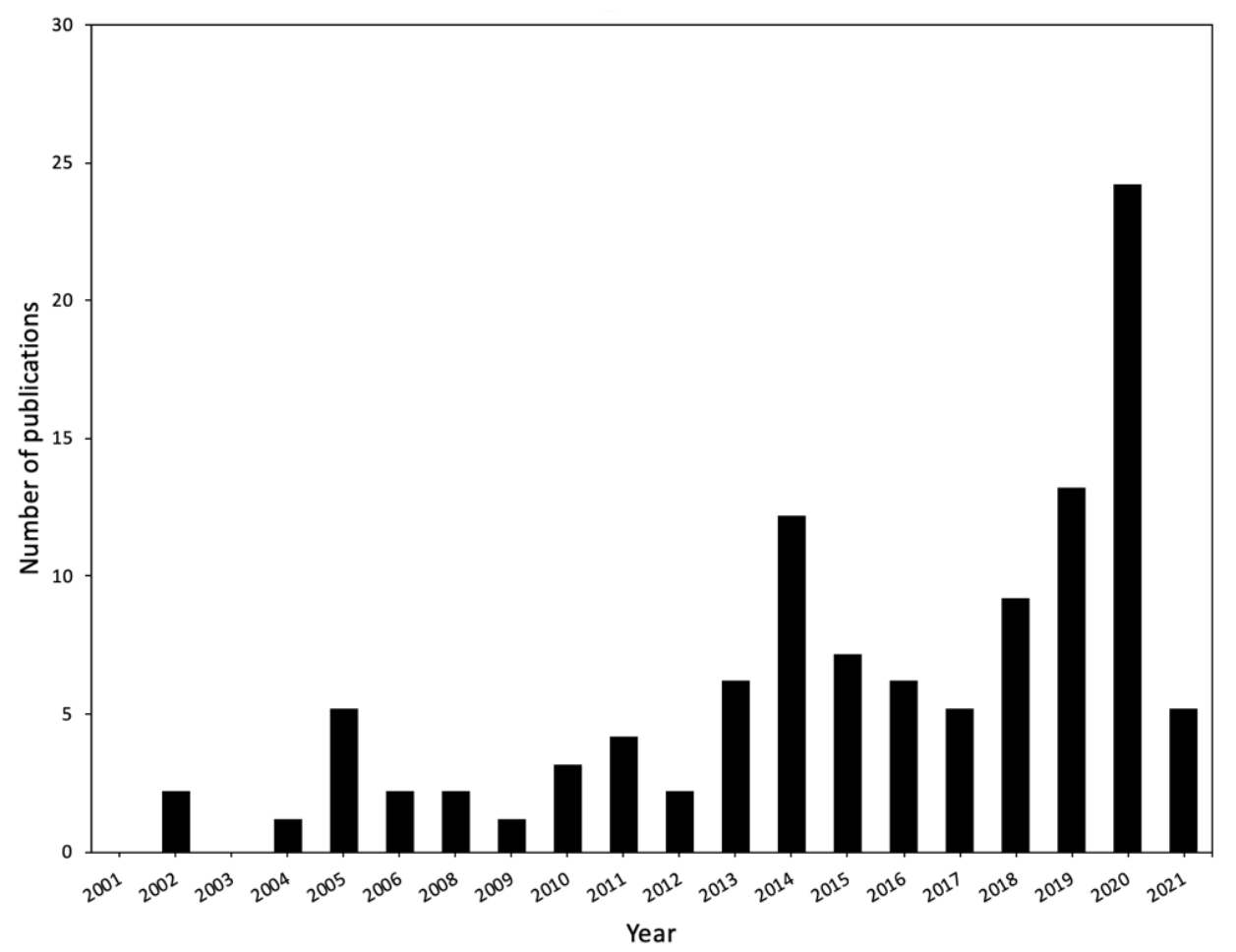

Figure 1. Number of publications per year related to sorghum drought stress since 2001. Keywords used in searches on the PubMed database included "sorghum water limitation, sorghum water deficit" with additional terms, such as "transcriptomics, proteomics, metabolomics". Database was accessed on 14 March 2021.

\section{General Plant Responses to Drought Stress}

Water is essential to all life forms. It maintains cell turgidity and structure in plants and is a basic requirement for growth, physiological and biochemical processes [55]. Nonetheless, different plant species may have varying water requirements to support normal growth and development. For example, among cereal crops, sorghum requires less water than maize, barley (Hordeum vulgare), and wheat (Triticum aestivum) [3]. However, as stated earlier, most plant species experience some level of drought stress (also known as water stress, osmotic stress, dehydration stress, or water deficits) at one or more growth stages during their life cycles. The term 'drought' describes periods of insufficient soil moisture content to meet the needs of a plant [56]. Consequently, plants alter their morphology, physiology, and biochemistry to mitigate the damage caused by primary and secondary effects of water scarcity and resume growth [57-60]. These plant responses are broadly categorized as drought escape, avoidance, and tolerance mechanisms and have been extensively described in $[57,61-63]$. Drought escape refers to plants remaining dormant during periods of water stress or rapidly completing growth cycles before the onset of the drought season $[57,61,62]$. Drought avoidance involves morphological/anatomical changes to allow the maintenance of high plant water potential during drought $[57,61]$ and is primarily achieved in one of three ways: Maintaining high water uptake through an extensive root system; Storing water in succulent tissues, and reducing transpiration water loss through numerous leaf modifications and adaptations that decrease total leaf surface area, and/or increase stomatal control and cuticular resistance $[57,61,62]$. However, drought tolerance mechanisms involve stress recognition and signaling events, followed by alterations in gene, protein and metabolite expression to alleviate the stress damage and regulate stress-inducible gene expression $[58,59,64,65]$.

Water deficits also affect the biosynthesis and catabolism of several hormones in plant tissues which in turn modulate many physiological processes [62]. For example, during drought stress, abscisic acid (ABA) and ethylene levels increase, while those of 
gibberellins, auxins and cytokinins decrease [55,61,62]. ABA, a well-known root-to-shoot stress signaling compound controls stomatal closure and the expression of stress genes during drought [66], while ethylene functions in leaf abscission [61]. These processes are important in conserving water and alleviating osmotic stress damage imposed by drought.

Likewise, sorghum responses to drought stress involve changes in morphology, physiology, and/or molecular activities. Amelework et al. [67] published a comprehensive review of physiological mechanisms employed by sorghum plants in response to water deficits and is highly recommended for further reading. Another review focused on general responses of sorghum to abiotic stresses [68], while Blum [69] compiled a comprehensive book chapter on sorghum physiology under normal growth conditions and in response to stress factors. Some drought avoidance mechanisms of this crop include changes in root structure, distribution, and depth [70], a decrease in stomatal conductance [71], retention of chlorophyll content [72], increased biosynthesis of epicuticular wax [73,74], and its deposition on leaf blades $[75,76]$.

Undoubtedly, whole-plant responses to drought stress are complex and involve the coordinated responses of tissues, cells, their compartments and composite macromolecules [77]. Consequently, plant scientists are now employing systems biology approaches [78], including "omics" technologies [79], to study the spatial and temporal expression changes of transcripts, proteins, and metabolites in response to abiotic stresses [80]. Such experimental approaches are both integrative and complementary, as they seek to unravel the network of biochemical pathways, their interactions, dynamics, and regulatory nodes during stress response [78]. Cramer and co-workers [80] have already given an excellent review of systems biology studies of plants in response to abiotic stress, and is recommended for further reading. However, similar reviews on sorghum are limited. Therefore, in the current review, we focus on studies that have employed transcriptomics and proteomics workflows to understand how sorghum plants respond to limited water supply.

\section{Sorghum Transcriptomics Studies in Response to Drought Stress}

Transcriptomics is the large-scale analysis of expressed RNAs in an organism, at a particular moment in time of a growth stage and/or in response to an environmental stimulus $[81,82]$. Although mRNAs are translated into proteins, non-coding sequences play critical regulatory functions during normal plant growth, including stress responses $[83,84]$. Techniques used to study transcripts are diverse, ranging from Northern blotting and hybridization methods, expressed sequence tags (ESTs), reverse transcriptase quantitative PCR (RT-qPCR), serial analysis of gene expression (SAGE) to RNA microarray, and RNA sequencing (RNA-seq) (reviewed by Lowe et al. [82]). Currently, microarrays and RNA-seq techniques are most commonly used in studies of the plant transcriptome, and each method has its pros and cons [82].

Transcriptomic studies of sorghum plants under drought stress have also used a broad spectrum of RNA profiling techniques, plant tissues, experimental designs and water stress treatments [19,73,74,85-94], as summarized in Table 2. Earlier studies investigated a dehydrin mRNA expression pattern in drought-stressed sorghum tissues using Northern blotting and hybridization methods against a ${ }^{32} \mathrm{P}$ labeled maize dehydrin cDNA probe $[85,86]$. Dehydrins are late embryogenesis-abundant (LEA) D-11 family proteins that accumulate in dehydrated tissues and possibly act as stabilizers of cell components $[95,96]$. Cheng and co-workers [85], exposed 10-day old sorghum seedlings to a slow dehydration process in a closed chamber with $3 \mathrm{M} \mathrm{NaCl}$, and sampled shoots over $22 \mathrm{~h}$. Results showed the presence of a drought-induced sorghum dehydrin transcript, whose accumulation increased with prolonged exposure to the dehydration stress. Similarly, Wood and Goldsborough [86] reported increased levels of a dehydrin (DHN1) mRNA in both sorghum seedlings and mature plants exposed to water limitation. However, this transcript was not detected in well-watered plants or those recovering from drought. The authors concluded that both the DHN1 mRNA and its protein are drought-inducible in sorghum tissues [86] and possibly hold a central role in drought adaptation $[95,96]$. 
Table 2. Summary of transcriptome studies of sorghum whole-plant systems under drought stress.

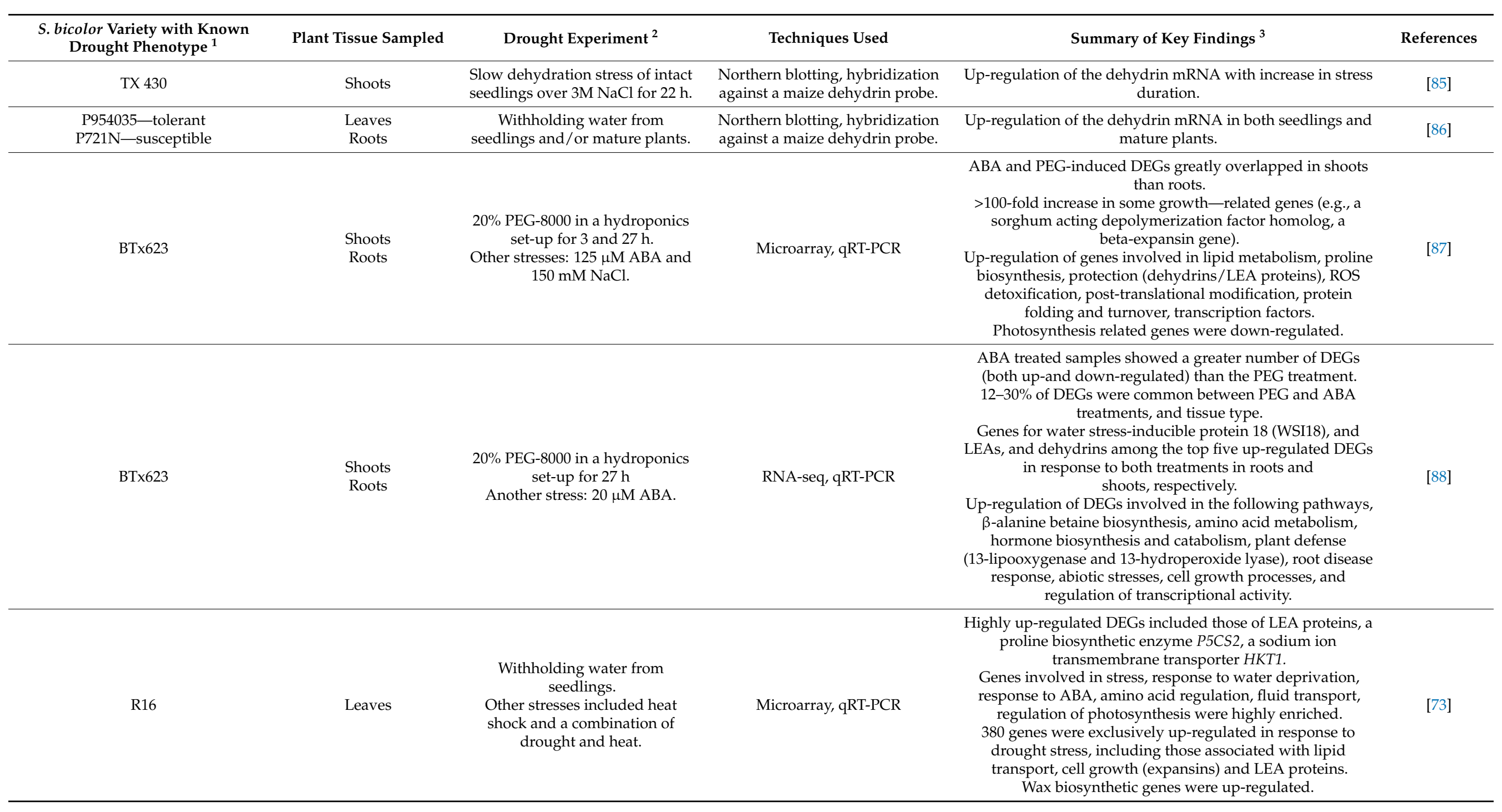


Table 2. Cont.

\begin{tabular}{|c|c|c|c|c|c|}
\hline $\begin{array}{l}\text { S. bicolor Variety with Known } \\
\text { Drought Phenotype }{ }^{1}\end{array}$ & Plant Tissue Sampled & Drought Experiment ${ }^{2}$ & Techniques Used & Summary of Key Findings ${ }^{3}$ & References \\
\hline $\begin{array}{l}\text { IS22330-tolerant } \\
\text { IS20351—susceptible }\end{array}$ & Leaf meristem & $\begin{array}{l}\text { Withholding water } \\
\text { from seedlings. }\end{array}$ & RNA-seq, qRT-PCR & $\begin{array}{l}\text { Higher constitutive expression of genes involved in the } \\
\text { secondary metabolic process and GST activity in the } \\
\text { drought-tolerant variety. } \\
\text { Alternative splicing events increased in the drought-tolerant } \\
\text { variety following stress. } \\
1599 \text { and } 636 \text { DEGs identified in drought-susceptible and } \\
\text { drought-tolerant varieties, respectively. } \\
559 \text { and } 78 \text { DEGs were both unique to, and up-regulated in } \\
\text { the drought-susceptible and drought-tolerant } \\
\text { varieties, respectively. } \\
\text { The susceptible variety metabolized carbohydrates while the } \\
\text { tolerant one activated amino acid biosynthesis in response } \\
\text { to drought. }\end{array}$ & [74] \\
\hline South African landrace-LR6 & Leaves & $\begin{array}{l}\text { Progressive water stress and } \\
\text { re-watering as follows: } \\
\text { Mild stress ( } 4 \text { days of } \\
\text { withholding water), } \\
\text { Severe stress ( } 6 \text { days of } \\
\text { withholding water), } \\
\text { Re-watering for } 5 \text { h after } 7 \text { days } \\
\text { of water stress. }\end{array}$ & Microarray, qRT-PCR & $\begin{array}{l}\text { The number of DEGs in general, and that of transcription } \\
\text { factors (TFs) were greatest under severe stress > mild stress > } \\
\text { recovery conditions. } \\
\text { TF-related genes were highly responsive to water } \\
\text { deprivation and re-watering. } \\
\text { Other examples of highly up-regulated DEGs include those } \\
\text { for mitochondrial transcription termination Factor (mTERF), } \\
\text { anion-transporting ATPase family and LEA proteins (mild } \\
\text { stress); putative homology to Abscisic acid-Insensitive } 2 \\
\text { (ABI2), mannosyltransferase, acid } \\
\text { phosphatase/oxidoreductase/transition metal ion binding } \\
\text { (severe stress); protein kinase, zinc ion binding, and } \\
\text { chloroplast chaperonin } 10 \text { proteins (re-watered samples). }\end{array}$ & [89] \\
\hline
\end{tabular}


Table 2. Cont.

\section{S. bicolor Variety with Known} Drought Phenotype ${ }^{1}$

\section{Plant Tissue Sampled}

\section{Drought Experiment ${ }^{2}$}

Withholding water from seedlings for 7 days, and sampling plant tissue from:

XGL-1-tolerant Leaves, Roots mild drought (RWC 60\%), rere-watered (severe drought days).$$
\text { days) }
$$

BTx623 and SC56-resistant Tx7000 and PI-482662—-sensitive
Whole seedlings
20\% PEG-8000 applied on 8-day old seedlings growing in nutrient medium for 1 and $6 \mathrm{~h}$.
Summary of Key Findings ${ }^{3}$

510,559 and 3,687 DEGs in leaf samples, and 3,368, 5,093, and 4,635 in root samples of mild drought, severe drought and re-watered plants.

and re-watered plants.
More DEGs in roots than leaves

Most enriched GO terms of DEGs in both tissues included a response to stimulus, temperature stimulus, light intensity,

ABA stimulus, and response to water deprivation.

20 and 130 DEGs common to all three treatments were

involved in hormone stimulus pathway in leaves and

$$
\text { roots, respectively. }
$$

ABA biosynthetic genes were up-regulated in roots in response to drought but down-regulated in re-watered samples, while auxin signaling-related genes showed a reciprocal expression pattern.

4 and 44 TF genes responded to all three treatments in leaves and roots, respectively.

Expansins were up-regulated during recovery from stress,

but down-regulated during water deprivation.

The total number of DEGs was greater at $6 \mathrm{~h}$ than $1 \mathrm{~h}$.

42 and 129 DEGs were common to all varieties at $1 \mathrm{~h}$ and $6 \mathrm{~h}$ of stress, most of which were up-regulated.

Early responses to PEG treatment included genes for hormone signaling and TFs.

Late responses to PEG treatment included genes involved in secondary metabolism, heat shock and ROS detoxification processes.

Examples of highly up-regulated genes common to all varieties at both time points include those of WSI18, alpha-amylase and GST.

Examples of genes up-regulated only in the drought-resistant varieties include LEAs, TFs, signaling, and lipid

References metabolism-related genes. 
Table 2. Cont.

\begin{tabular}{|c|c|c|c|c|c|}
\hline $\begin{array}{l}\text { S. bicolor Variety with Known } \\
\text { Drought Phenotype }{ }^{1}\end{array}$ & Plant Tissue Sampled & Drought Experiment $^{2}$ & Techniques Used & Summary of Key Findings ${ }^{3}$ & References \\
\hline $\begin{array}{c}\text { SC56-tolerant } \\
\text { Tx7000—susceptible }\end{array}$ & Leaves & $\begin{array}{l}\text { Withholding water at anthesis for } \\
13 \text { days. }\end{array}$ & RNA-seq & $\begin{array}{l}\text { Higher constitutive expression of genes in the tolerant } \\
\text { variety than the susceptible variety, with enriched GO terms } \\
\text { including translation, amino acid metabolism, carbohydrate } \\
\text { metabolism, and cell homeostasis-related processes. } \\
363 \text { and } 263 \text { DEGs genes in the tolerant and susceptible } \\
\text { variety, respectively. } \\
\text { The tolerant variety responded to drought by up-regulating } \\
\text { genes involved in translation, gene expression, metabolism, } \\
\text { redox homeostasis, and drought regulatory genes, } \\
\text { among others. }\end{array}$ & [92] \\
\hline $\begin{array}{l}\text { RTx } 430 \\
\text { BTx642 }\end{array}$ & $\begin{array}{l}\text { Leaves } \\
\text { Roots }\end{array}$ & $\begin{array}{l}\text { Plants grew over } 17 \text { weeks from } \\
\text { seedlings to maturity and were } \\
\text { sampled at weekly intervals. } \\
\text { Watering withheld during } \\
\text { pre-flowering and post-flowering } \\
\text { growth stages. } \\
\text { Other plants were re-watered } \\
\text { after pre-flowering } \\
\text { drought stress. }\end{array}$ & RNA-seq & $\begin{array}{c}\text { A large-scale study with } 198 \text { leaf and } 198 \text { root transcriptomes. } \\
10272 \text { DEGs observed accounting for } 44 \% \text { of all } \\
\text { expressed genes. } \\
\text { 10\% of all expressed genes were modulated within the first } \\
\text { week of drought stress treatments. } \\
\text { Roots exhibited a greater number of DEG than leaves. } \\
\text { Genotype specific differences were observed for both } \\
\text { constitutive and drought-induced response. } \\
\text { Tissue and developmental stage-specific differences in } \\
\text { transcripts were observed. } \\
\text { GST and proline biosynthetic genes were among the DEG } \\
\text { with genotypic differences in expression. }\end{array}$ & [19] \\
\hline $\begin{array}{l}\text { M35-1-tolerant } \\
\text { C43-susceptible }\end{array}$ & Leaves & $\begin{array}{l}\text { Grown for } 30 \text { days after sowing. } \\
\text { Water withheld until leaf relative } \\
\text { water content of } 60-65 \% \text {. }\end{array}$ & $\begin{array}{l}\text { TruSeq small RNA library prep } \\
\text { and Illumina sequencing }\end{array}$ & $\begin{array}{c}96 \text { miRNAs regulated specifically by drought stress: } 32 \text { up-, } \\
49 \text { down-, } 15 \text { genotype-contrasting regulation. } \\
\text { The work demonstrated a genotype-dependent drought } \\
\text { stress response, with the sensitive genotype having } 17 \\
\text { drought differentially expressed miRNAs, with } 18 \text { in the } \\
\text { tolerant line. } \\
\text { tasi-RNA targetsmiR390-directed TAS3 homologs and auxin } \\
\text { response factors. }\end{array}$ & [93] \\
\hline
\end{tabular}


Table 2. Cont.

\begin{tabular}{|c|c|c|c|c|c|}
\hline $\begin{array}{l}\text { S. bicolor Variety with Known } \\
\text { Drought Phenotype }{ }^{1}\end{array}$ & Plant Tissue Sampled & Drought Experiment ${ }^{2}$ & Techniques Used & Summary of Key Findings ${ }^{3}$ & References \\
\hline $\begin{array}{c}\text { HSD } 2945 \\
\text { HSD } 3220 \\
\text { HSD } 3221 \\
\text { HSD } 3222 \\
\text { HSD } 3223 \\
\text { HSD } 3226 \\
\text { HSD } 5299 \\
\text { HSD 5373 } \\
\text { Arfa Gadamak-tolerant } \\
\text { N98 } \\
\text { Atlas }\end{array}$ & Leaves & $\begin{array}{l}\text { Control plants watered every } 10 \\
\text { days. } \\
\text { Drought-stressed plants watered } \\
\text { on 21-day interval. }\end{array}$ & qRT-PCR targeting 8 microRNA & $\begin{array}{l}\text { Expression profiling of } 8 \text { microRNAs known to be } \\
\text { down-regulated during abiotic stress (drought and control) } \\
\text { across } 11 \text { sorghum genotypes. }\end{array}$ & [94] \\
\hline
\end{tabular}

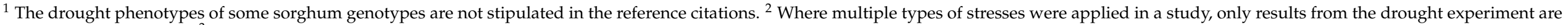

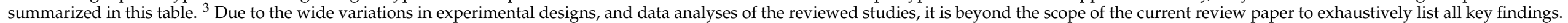
For a comprehensive list of the results, readers are referred to the original research papers. 
Apart from anchoring plants into the soil, roots also play a critical role in drought stress signaling processes. They sense the development of soil moisture deficits and transmit signals-including ABA, to other plant tissues to elicit stress responses [66,97]. Buchanan et al. [87] conducted a cDNA microarray-based transcriptomics study of shoots and roots of the sorghum cultivar BTx623 in response to $20 \%$ polyethylene glycol (PEG)induced osmotic stress, $\mathrm{NaCl}$-induced salinity, and exogenous ABA. Tissue sampling was done at 3 and $27 \mathrm{~h}$ to investigate temporal changes in transcript expression and to reduce circadian cycling interference on the data. The study reported about 2200 differentially expressed genes (DEGs) in response to the three different treatments, with some being unique to a plant tissue, treatment, or sampling time point. Collectively, the DEGs had putative functions in signaling, regulation and gene expression, growth, metabolism, transport, protection from dehydration, reactive oxygen species (ROS) detoxification, and plant defense, while other genes had unknown functions. Examples of up-regulated genes include those of various transcription factors, signaling proteins, LEAs, dehydrins, heat shock proteins (HSPs), small HSPs, expansins, and several ROS detoxification enzymes. In addition, the expression levels of genes involved in the biosynthesis of ABA, proline, and the raffinose family of oligosaccharides (RFOs) were also enhanced [87].

However, since the microarray-based study by Buchanan and co-workers [87] was conducted prior to the release of the sorghum genome sequence [23], it was later discovered that the sorghum-microarray probes used had limited gene coverage [88]. Expanding on their previous study, Dugas and co-workers [88] conducted RNA-seq analyses of roots and shoots of the same sorghum variety in response to $20 \%$ PEG, and exogenous ABA treatments. Samples were collected after $27 \mathrm{~h}$ to mimic the research group's earlier study [87]. The study found 28,335 genes with transcriptional activity, of which between 1000-3200 genes were differentially expressed depending on the tissue type or treatment. The results also revealed that exogenous $\mathrm{ABA}$ modulated the expression of a greater number of genes than PEG. In addition, between $12-30 \%$ of the DEGs were common to both treatments depending on the tissue type, possibly indicating the central role of ABA in osmotic stress response. Examples of the DEGs included those involved in the biosynthesis of several plant hormones, metabolism of amino acids and other osmoprotectants, cell growth, ROS detoxification, and defense pathways against pathogen attack. The families of up-regulated transcripts were generally similar to those previously reported by Buchanan et al. [87] including a wider pool of transcription factors, a signaling CLAVATA3 protein, the water stress-inducible protein 18 (WSI18) and biosynthesis enzymes of the osmoprotectant $\beta$-alanine betaine [88].

Similarly, Zhang and co-workers [90] investigated the transcriptomic profiling of leaves and roots of a drought-tolerant sorghum variety XGL-1 in response to drought stress using RNA-seq analysis. Sorghum seedlings were exposed to either mild or severe water deprivation for 7 days before re-watering some for an additional 2 days. Control plants were well-watered throughout the experiment. Between 19,000-22,000 genes were identified in the two tissue types, of which 13,285 were differentially expressed in response to the various treatments. In general, roots exhibited more DEGs than leaves, possibly implicating roots in stress perception and relay of signals during drought response. Gene Ontology (GO) enrichment analyses revealed overlaps in the over-represented biological processes between roots and leaves, including response to stimuli, such as ABA, temperature, and light intensity, response to water deprivation, and response to oxidative stress. In addition, root samples had DEGs with carbohydrate-related metabolic processes such as sucrose metabolic process and raffinose family oligosaccharide biosynthetic process which were not detected in leaves. Such tissue-specific gene expression patterns possibly highlight the increased importance of carbohydrates in roots during drought response and/or the putative functions of sugars in signaling processes.

Other remarkable observations in the study [90] relate to a shift in hormonal balance during drought and recovery from stress. For example, DEGs involved in ABA biosynthesis and catabolism were up-regulated in roots during drought, but down-regulated during 
recovery from stress, with an inverse expression pattern of DEGs involved in the auxin signal pathway. These results underscore the distinctive roles of various plant hormones in response to water deficits [55,62]. In addition, it is well-known that plants exposed to environmental stresses tightly regulate gene expression to re-direct plant resources for the maintenance of critical cell processes and homeostasis [65]. Zhang et al. [90] also identified DEGs of transcription factors (TFs) in response to water deficits, with only four in leaves but 66 in roots. This observation further highlights the central role of the root transcriptional activities in driving plant responses to water deficits. The identified TFs possibly regulate the expression of many functional and protective genes and downstream proteins required for drought response and adaptation.

Leaves are the prime photosynthetic tissue of most crops and also serve as sites for gas exchange and transpiration [55]. Drought stress affects carbon assimilation and fixation [62], which contributes to reduced plant growth and yield [11]. Furthermore, heat and drought stresses are usually concurrent under field conditions, exerting even greater detrimental effects on plant growth than each stress alone [98,99]. Both stresses cause the over-production and accumulation of reactive oxygen species (ROS) in cells [100], which lead to oxidative damage of macromolecules and photosynthetic machinery [101,102]. As with other stress factors, plants respond to the effects of drought and/or heat stresses by reprogramming gene expression [100]. Consequently, Johnson and co-workers [73] investigated the transcriptional responses of leaves of R16 sorghum seedlings in response to drought, heat, and a combination of the two stresses using DNA-microarray analysis. The microarray chip consisted of 28,585 gene spots, which correlated with the draft sorghum genome at the time. In the study, 14-day old seedlings were either exposed to drought by withholding water for 3 days at $28^{\circ} \mathrm{C}, 3 \mathrm{~h}$ heat shock treatment at $50^{\circ} \mathrm{C}$, and a combination of the two stresses while well-watered controls were kept at $28^{\circ} \mathrm{C}$. The study reported transcriptional changes in about $3.5 \%, 18 \%$ and $22 \%$ of the genes on the microarray chip in response to drought, heat and combined stresses, respectively. Examples of the highly up-regulated transcripts in response to drought included genes of LEA proteins, P5CS2-a proline biosynthetic gene, and HKT1 - a sodium ion transmembrane transporter. GO enrichment analyses also identified the over-representation of genes involved in responses to stress such as water deprivation, responses to ABA, regulation of photosynthesis, fluid transport, and amino acid metabolism. In addition, promoter motif analysis of the upregulated drought-responsive genes identified the ABA-responsive element (ABRE) motif as highly represented.

Although overlaps were observed in some DEGs across the three treatment groups (drought, heat, and a combination of the two), others were unique to each of the treatments [73], signifying crosstalk and specificity in plant responses to an array of stresses [103]. For example, 380 genes were up-regulated only in the drought-stressed plants, including transcripts of specific LEA proteins, expansins, lipid transport, and lipid transfer proteins. Interestingly, when Johnson et al. [73] compared their sorghum drought-responsive transcripts to those reported by Dugas et al. [88] in response to 20\% PEG-induced osmotic stress, only a third of the genes where common between the two studies. This indicates that different types of water deficit treatments may trigger different response pathways [73]. As reviewed by Osmolovskaya and co-workers [104], drought models used in plant studies are diverse, with each set-up potentially exerting intrinsic effects of water limitations to the experimental plant system-leading to somewhat heterogeneous results. Consequently, the most enriched biological processes in the study by Dugas and co-workers [88] included responsive to stress, and ROS, while wax biosynthetic processes were over-represented in the study by Marc Knight's group [73].

Landraces are rich sources of untapped genetic variation that can be harnessed for the development of elite crop cultivars [6]. Accordingly, Denvarain et al. [89] analyzed changes in the leaf transcriptome of a South African sorghum landrace LR6 in response to water deficits using cDNA microarrays. The plants were exposed to three watering regimesmild stress, severe stress and re-watering, and all transcripts were compared to those of 
well-watered controls. Out of the 35,899 transcript probes on the sorghum-microarray chip, a total of 368,414 , and 137 were differentially expressed in response to the mild stress, severe stress, and re-watering conditions, respectively. Although the DEGs covered a wide range of functional categories, TFs largely dominated the drought-responsive transcripts identified in the study and were more prominent in severely stressed leaves. These results underscore the critical role of TFs in regulating gene expression during drought response. Similar to other transcriptomics studies reviewed above, the significantly enriched transcripts belonged to the following biological processes: response to abiotic stimulus, homeostatic process, regulation of biological quality, cellular homeostasis, and response to stimulus. Similar to reports by Dugas et al. [88] genes involved in the biosynthesis of $\beta$-alanine betaine were also up-regulated [89].

Although the studies reviewed above provided invaluable information on DEGs in drought response of plant tissue(s) from a single sorghum variety, comparative studies between two $[19,74,92,93]$ or more $[91,94]$ genotypes with contrasting drought phenotypes are important in identifying drought tolerance-related genes for potential application in molecular breeding [62]. On this premise, Fracasso and co-workers [74] used RNA-seq to study the global transcriptome changes of leaf meristems in two sorghum varieties with contrasting water use efficiency in response to drought. Both genotypes were exposed to similar levels of water deprivation before RNA sequencing, and data analyses were extensively performed within and between genotypes to identify trends in constitutive gene expression versus those induced by drought. The results revealed that water deficits significantly increased alternative splicing events in the drought-tolerant genotype (IS22330) compared to the sensitive genotype (IS20351). Alternative splicing is one of many gene regulatory mechanisms employed by plants to increase protein diversity and function during normal growth/physiological processes, and in response to adverse environmental conditions [105-107], and may contribute towards drought resistance of some sorghum genotypes.

Some overlap in DEGs and GO terms were also identified between the two genotypes. However, the authors highlighted a particularly high constitutive expression of genes involved in secondary metabolism, including those of non-enzymatic antioxidant compounds and glutathione transferase (GST) activity in the tolerant genotype, possibly contributing to its inherent drought-superior traits compared to the sensitive genotype [74]. The authors argue that for this reason, the drought-tolerant genotype exhibited a lesser number of DEGs in response to drought, totaling 636, compared to 1599 in the drought-sensitive genotype. Furthermore, GO terms such as response to abiotic stimulus, oxido-reductase activity and response to stress were significantly down-regulated in the susceptible variety compared to the tolerant type. However, cuticular wax biosynthesis genes remained unchanged in the tolerant genotype in response to drought stress but were elevated in the drought-sensitive genotype, possibly to increase wax deposits for improved water conservation [75].

Likewise, Azzouz-Olden et al. [92] conducted a comparative RNA-seq analysis of sorghum leaf tissue following post-anthesis drought in two sorghum genotypes with contrasting tolerance to post-flowering drought stress. Similar to the results of Fracasso and co-workers [74], the authors [92] reported higher constitutive expression of genes involved in redox homeostasis, translation, and the biosynthesis of a range of metabolites in the drought-tolerant genotype SC56 compared to Tx-7000, which is sensitive to post-flowering drought stress. Following water deprivation, the drought-tolerant genotype exhibited the up-regulation of antioxidation-related genes such as GST, superoxide dismutase, peroxidases, biosynthetic enzymes of non-enzymatic antioxidants (such as tocopherols and glutathione), and genes involved in transmembrane transporters. Thus, biological processes that are either highly constitutively expressed or over-represented in the drought-tolerant genotypes during water stress compared to the sensitive genotypes could possibly represent putative genes that confer drought tolerance traits in these sorghum genotypes. 
Some sorghum genotypes tolerate either pre-flowering or post-flowering drought stress and may exhibit differential responses to water deficits during these developmental stages [16]. Varoquaux et al. [19] conducted a large-scale transcriptome analysis of two field-grown sorghum genotypes in response to pre- and post-flowering drought stress, as well as recovery from pre-flowering drought. The genotypes used, RTx430 and the staygreen BTx642, are tolerant to pre-flowering and pre-flowering drought stress, respectively. Leaf and root samples of both genotypes were collected at weekly intervals over 17 weeks and analyzed for drought transcriptome changes relative to those of well-watered controls. RNA sequencing was performed on 198 root and 198 leaf samples, followed by GO and enrichment analyses. The study revealed a large transcriptional response to drought, with 10,727 genes accounting for $44 \%$ of the expressed genes showing changes in response to the various treatments. However, $10 \%$ of the expressed genes showed changes to water deprivation within the first week of the drought treatment, indicating a quick response to water deficits.

Furthermore, after re-watering, about $75 \%$ of the pre-flowering drought-responsive genes had similar expression levels to those of well-watered control plants. As reported by Zhang and co-workers [90], root tissues exhibited a greater number of DEGs than leaves, possibly reinforcing the role of roots in drought sensing and signal transduction pathways [19]. The study's other key findings include differences in constitutive and droughtinduced transcriptional activities between the two genotypes, including GST and proline biosynthetic genes. Overall, this comprehensive transcriptome study revealed the complex spatial and temporal drought responses between genotypes with contrasting phenotypes.

In another comparative study, Abdel-Ghany and co-workers [91] exploited the vast genetic diversity of sorghum and analyzed transcript changes of drought-stressed 8-day old seedlings of four genotypes. Osmotic stress was imposed using 20\% PEG, and samples were assessed for early $(1 \mathrm{~h})$ and late $(6 \mathrm{~h})$ changes in the transcriptome using RNA-seq. The four genotypes used, Bx623, SC56, Tx-7000, and PI482662, were previously reported to possess some level of drought tolerance either at pre-anthesis and pre-flowering or post-flowering growth stages (see references in [91]). However, the authors categorized the genotypes as drought-resistant (Bx623 and SC56) and sensitive (Tx-7000 and PI482662) based on root length traits in response to PEG-induced osmotic stress [91]. Five notable trends emerged from this study. All four sorghum genotypes responded to PEG-induced osmotic stress by up-regulating a greater number of DEGs at $6 \mathrm{~h}$. Unique and common DEGs were reported across all genotypes, and some common DEGs are well-known drought-responsive genes such as those of TFs, hormone signaling, stress, and detoxification/antioxidant processes. Early responses to PEG-induced osmotic stress revealed the involvement of genes associated with $\mathrm{ABA}$, jasmonic acid, and auxin hormone signaling and TFs, while late responses included genes involved in abiotic stress, secondary metabolism, heat shock, and GST synthesis. However, limited overlap between DEGs at the two, time points was observed. Some of the DEGs unique to the drought-resistant lines Bx623 and SC56 included LEA genes, TFs, signaling, and lipid metabolism-and these could be involved in conferring drought tolerance to the drought-resistant sorghum lines.

The non-coding RNAs are increasingly being studied for their role in post-transcriptional regulation. Katiyar et al. [93] investigated the regulatory roles of two small, non-coding RNAs (sRNAs), namely microRNAs (miRNAs) and trans-acting small interfering RNAs (tasi-RNAs), in sorghum drought-responsive gene expression. The study compared sRNA libraries from susceptible (C43) and drought-tolerant (M35-1) sorghum lines under both drought stress and control conditions. More than 500 novel miRNAs were identified, but only 96 were drought-unique, with 32 up-, 49 down-regulated ( $\geq 2$-fold change), and 15 genotype-contrasting drought-regulated expression patterns. Of these 96 miRNAs, 63 showed genotype opposing regulation. Of these, 44 genes were up-regulated in the drought-tolerant genotype, but down-regulated in the susceptible (C43) genotype, while 19 were down-regulated M35-1 and up-regulated in C43. Genotype-dependent drought stress responses were also observed, with 17 miRNAs differentially regulated in the sensitive 
genotype and 18 miRNAs in the tolerant genotype. A total of 1300 potential genomic targets were predicted for the novel and known 432 miRNA families identified, with no targets identified for the remaining 96 new miRNA families. Predicted miRNAs were involved in the regulation of metabolic, cellular, and biological processes, and responses to stimuli, with a number identified previously in both sorghum and other crops to be active during drought stress. Two TAS3 gene orthologs, targeted by miR390, were identified and together confirmed the presence of a sorghum miR390-Tas3 pathway and a possible role in the auxin signaling pathway. Six miRNA families were predicted to target peroxidases, i.e., enzymes involved in restricting ROS build-up.

Hamza et al. [94] profiled 11 elite sorghum lines with 8 miRNAs previously shown to be down-regulated during abiotic stress. The selected miRNAs had predicted target transcripts across 66 different GO terms, with the main categories belonging to biological processes, cellular components, and molecular function. The 8 selected miRNAs' expression profiles were compared under well-watered control and drought stress conditions. The results showed that miRNA profiles varied largely between genotypes, and no uniform miRNA expression pattern could be identified. Based on this, the authors suggested that sorghum drought tolerance could be a "fine-tuning mechanism" that varies between genotypes, therefore influencing growth and developmental processes-especially since many of the miRNAs studied had links to auxin signaling and ROS [94].

\section{Sorghum Proteomics Studies in Response to Drought Stress}

Proteomics is the large-scale analysis of expressed proteins in an organism, tissue, cell, or cellular compartment during normal development or in response to the changing environment $[108,109]$. As reviewed previously [110,111], proteomics technologies are diverse and broadly categorized into gel-based and non-gel-based techniques, coupled with mass spectrometry for protein identification and downstream bioinformatics analyses for putative functional characterization of the identified proteins. Earlier reviews have discussed the progress made in plant proteomics under a range of abiotic stresses and can be accessed for further reading [111-114]. In this section, we summarize proteomic studies of sorghum plants under drought stress. Compared to the sorghum whole-plant transcriptomic analyses discussed above, the complementary proteomic work of this crop is extremely limited to a few publications [71,115-117] (Table 3). This highlights the need for more studies to analyze the dynamics of sorghum proteomes in response to water deprivation as we seek to understand the molecular networks that contribute to the crop's natural resilience to drought.

In a pioneering proteomic study of sorghum leaves under drought stress, Jedmowski et al. [115] conducted a comparative two-dimensional difference gel electrophoresis (2D DIGE) analysis between drought-sensitive, 11,431 and tolerant, 11,434 sorghum accessions in droughtstressed and re-watered plants. The study reported proteome changes in both accessions in response to the treatments, with common and unique drought-responsive protein and/or expression patterns. The identified proteins have putative roles in metabolism, energy, transcription, protein synthesis, protein destination and storage, while some were unclassified. Further analysis of the drought-responsive proteins revealed that the drought-sensitive variety has increased levels of proteolytic enzymes, while those involved in transcriptional activity, synthesis, and stability of proteins were enhanced in the drought-tolerant sorghum variety. 
Table 3. Summary of proteomic studies of sorghum whole-plant systems under drought stress.

\begin{tabular}{|c|c|c|c|c|c|}
\hline $\begin{array}{l}\text { S. bicolor Variety with Known } \\
\text { Drought Phenotype }^{1}\end{array}$ & Plant Tissues & Drought Experiment & Techniques Used & Summary of Key Findings ${ }^{2}$ & References \\
\hline $\begin{array}{c}\text { 11434-tolerant } \\
11431 \text {-susceptible }\end{array}$ & Leaves & $\begin{array}{l}\text { Withholding water from } \\
\text { seedlings until soil water } \\
\text { potential of } 1 \mathrm{MPa} \text {, } \\
\text { Re-watering for } 24 \mathrm{~h} .\end{array}$ & $\begin{array}{l}\text { 2D-DIGE, } \\
\text { MALDI-TOF-MS }\end{array}$ & $\begin{array}{l}\text { Transcription, protein synthesis, protein destination and } \\
\text { storage-related proteins were generally more up-regulated } \\
\text { in the drought-tolerant varieties than the sensitive type in } \\
\text { response to drought and/or re-watering. } \\
\text { Proteases were up-regulated in the drought-sensitive variety } \\
\text { in response to water deprivation. }\end{array}$ & [115] \\
\hline $\begin{array}{l}\text { SA1441—tolerant } \\
\text { ICSB338—susceptible }\end{array}$ & Roots & $\begin{array}{l}\text { Withholding water from } \\
\text { seedlings for } 8 \text { days. }\end{array}$ & iTRAQ, qRT-PCR & $\begin{array}{c}\text { Common and unique drought-responsive proteins were } \\
\text { identified in the two varieties. } \\
\text { The tolerant SA1441 up-regulated transcription, protein } \\
\text { synthesis, protease inhibitors, signaling transduction, and } \\
\text { transporter-related proteins in response to water deprivation. } \\
\text { The sensitive ICSB338 down-regulated metabolism and } \\
\text { protein synthesis but increased the proteolysis. }\end{array}$ & [71] \\
\hline BTx623 & Roots & $\begin{array}{l}20 \% \text { PEG-6000 applied on } \\
\text { 16-day-old seedlings growing on } \\
\text { nutrient medium over } 24 \mathrm{~h} .\end{array}$ & $\begin{array}{l}\text { 2D-PAGE, } \\
\text { CBB-G250 staining, } \\
\text { MALDI-TOF-TOF MS }\end{array}$ & $\begin{array}{l}65 \text { drought-responsive root proteins (up- and } \\
\text { down-regulation) with a 2-fold change in abundance } \\
\text { detected on gels. } \\
52 \text { of the } 65 \text { proteins were positively identified. } \\
\text { The 3-topmost represented functional groups were energy } \\
\text { and carbohydrate metabolism, antioxidant/defense and } \\
\text { protein synthesis/processing/degradation. } \\
\text { Up-regulated proteins were mainly involved in } \\
\text { carbohydrate/energy/lipid metabolism, antioxidant } \\
\text { functions, stress response (LEA like-proteins), protein } \\
\text { synthesis and transport, regulation of transcription, and } \\
\text { signaling functions. }\end{array}$ & [116] \\
\hline $\begin{array}{l}\text { EI9-tolerant } \\
\text { Tabat-sensitive }\end{array}$ & Leaves & $\begin{array}{l}\text { Withholding water from 14-day } \\
\text { old seedlings for } 7 \text { days. }\end{array}$ & $\begin{array}{l}\text { Nanoflow UPLC, } \\
\text { MS }\end{array}$ & $\begin{array}{l}36 \text { proteins were detected. Of these, } 23 \text { were } \\
\text { drought-induced in either one or both sorghum varieties. } \\
\text { Identified proteins were involved in a range of functions, } \\
\text { including response to stress, metabolic processes, } \\
\text { photosynthesis, cell wall biosynthesis/degradation, and fatty } \\
\text { acid biosynthesis. }\end{array}$ & [117] \\
\hline
\end{tabular}

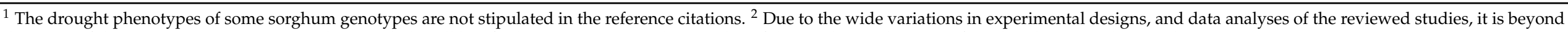
the scope of the current review paper to exhaustively list all key findings. For a comprehensive list of the results, readers are referred to the original research papers. 
Goche et al. [71] conducted a comparative root proteome analysis of two sorghum varieties in response to drought stress using the gel-free isobaric tags for relative and absolute quantitation (iTRAQ) technology. The sorghum varieties used ICSB338, and SA1441 are susceptible and tolerant to drought, respectively. In the study, drought stress was simulated by withholding water to young seedlings for 8 days prior to analyzing the root proteome. Of the 1169 and 1043 positively identified root proteins in the drought-sensitive and drought-tolerant varieties, 237 and 187 were responsive to drought, respectively. Further comparative analysis of these stress-responsive proteins revealed that 51 were common to both varieties, albeit with some differences in abundance levels. The rest, 186 and 136, were unique to ICSB338 and SA1441 sorghum varieties, respectively. Although the majority $(>70 \%)$ of the positively identified proteins were uncharacterized, bioinformatics tools were used to group the drought-responsive proteins into theoretical functional categories such as defense/detoxification, proteolysis, transporter/intracellular transport, metabolism, transcription, protein synthesis, proteolysis, signal transduction, and cell structure.

Further interrogation of the drought-responsive proteins revealed several notable trends within and between the two sorghum varieties [71]. For example, among the common proteins, those involved in signal transduction and defense/detoxification-related processes were generally up-regulated, but metabolism-related proteins were mostly downregulated. The unique proteins also depicted contrasting expression dynamics, which possibly contribute towards the differential performance of these two varieties under water-limited conditions. For example, the drought-superior variety, SA1441 responded to water deficits by increasing the abundance of proteins related to transcription, protein synthesis, protease inhibition, signaling, defense/detoxification-related processes compared to the drought-susceptible ICSB338. Conversely, ICSB338 increased the accumulation of proteolytic enzymes while down-regulating those involved in metabolism and protein synthesis. Thus, both proteomic studies [71,115] highlight the importance of droughtinduced transcriptional activity, and protein synthesis in increasing the pool of proteins, and downstream metabolites with protective and signaling roles during drought stress. In contrast, increased protein degradation and reduced metabolism are common responses among the drought-sensitive genotypes. However, further functional studies are required to elucidate the roles of these proteins in drought response.

Another recent study [116] also analyzed the root proteome changes of the Bx623 sorghum inbred line in response to a $24 \mathrm{~h}$ treatment in $10 \%$ PEG-induced osmotic stress using 2D gel electrophoresis and matrix-assisted laser desorption/ionization time-offlight tandem mass spectrometry (MALDI-TOF-TOF MS) analysis. The study reported 105 differentially accumulated proteins in response to the PEG treatment, with 65 of these with a 2-fold change in abundance. Of these proteins, 43 were up-regulated and 22 down-regulated. The majority of the stress-responsive proteins were involved in energy and carbohydrate metabolism, antioxidant and defense response, and protein synthesis/processing/degradation, further complementing a previous root proteomic study [71]. As observed in the comparative transcriptomics studies, putative functional groups of stress-responsive proteins identified in the drought-tolerant varieties possibly contribute to the tolerant nature of the sorghum accessions by producing proteins/metabolites responsible for maintaining cellular homeostasis under water stress.

\section{An Overview of Sorghum Molecular Responses to Drought Stress}

In summary, sorghum molecular responses to water deprivation involve stress perception/signaling events followed by gene, protein, and metabolite expression changes. The reviewed transcriptomics $[19,73,74,85-94]$ and proteomics [71,115-117] studies also affirm such complexities in drought tolerance mechanisms of the crop. However, because the studies employed a wide range of experimental designs, detailed comparisons between individual drought-responsive genes and proteins are difficult to perform across experiments. Nonetheless, we illustrate a generalized molecular response network of drought-stressed sorghum plants (Figure 2) using published [71,115] up-regulated pro- 
teomes of drought-tolerant sorghum varieties. These proteomic data are also largely supported by drought-responsive sorghum transcriptomes reported by Dugas et al. [88] and Johnson et al. [73].

\section{Perception of water deficits}

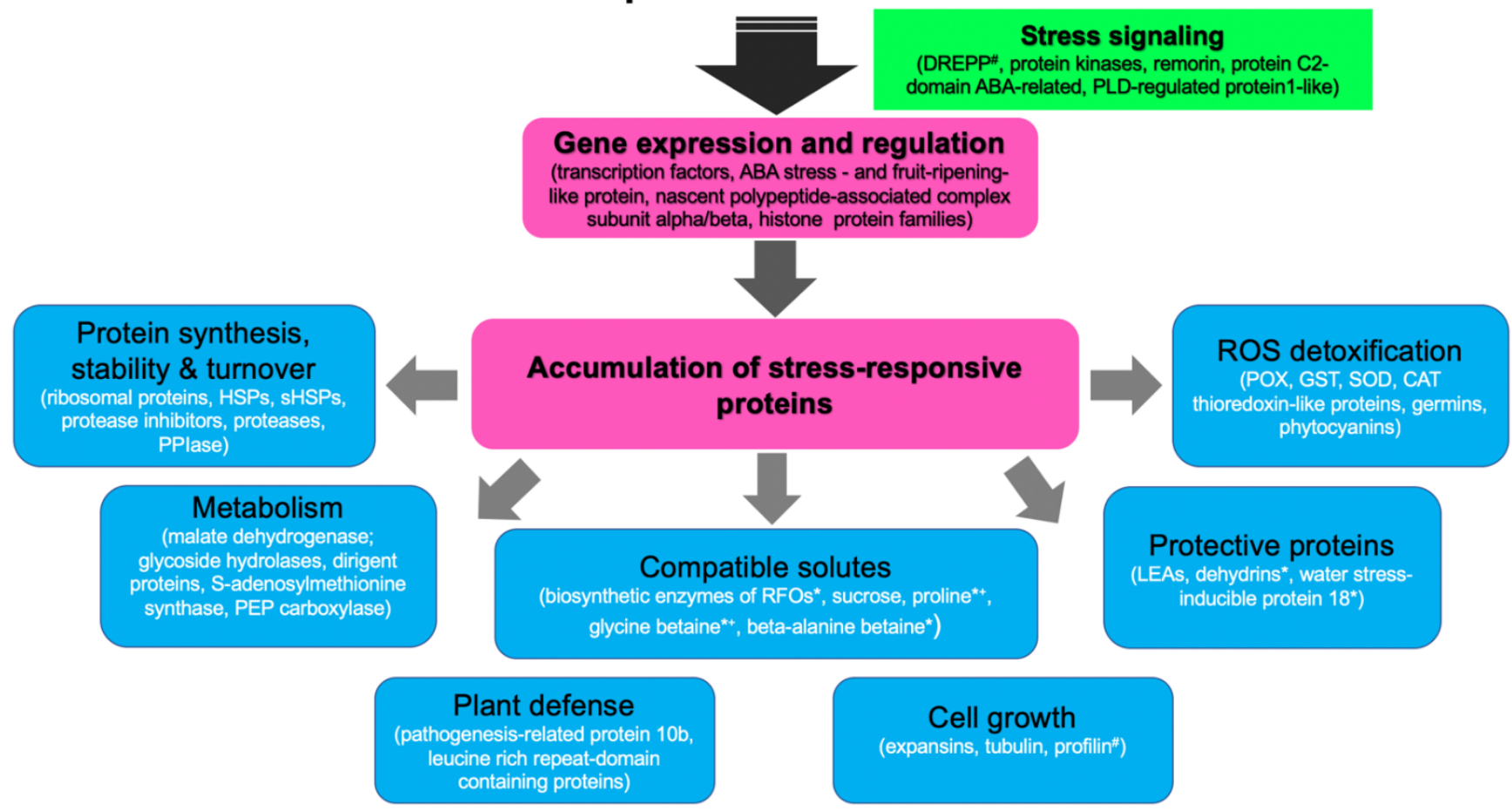

Figure 2. A generalized molecular response network of drought-stressed sorghum plants. Up-regulated root and leaf proteins of drought-tolerant sorghum genotypes were obtained from two drought proteomics studies [71,115] and their protein family names used to search similarly up-regulated genes in transcriptomics datasets [73,88]. Common gene families between the transcriptomics and proteomics studies were used to construct the diagram. ${ }^{\#}$ denotes proteins identified in the proteomics studies, ${ }^{*}$ denotes genes identified in transcriptomics studies, ${ }^{*+}$ denotes biosynthesis enzymes of compatible solutes identified in the transcriptomics studies, while the solute levels were reported by Goche et al. [71]. ABA, abscisic acid; CAT, catalase, DREPP, developmentally regulated plasma membrane polypeptide; GST, glutathione transferase; HSPs, heat shock proteins; sHSPs, small heat shock proteins; PEP, phosphoenolpyruvate; PLD, phospholipase D; POX, peroxidase, PPIase, peptidyl-proline isomerase, RFOs, raffinose family of oligosaccharides; ROS, reactive oxygen species; SOD; superoxide dismutase.

As expected, transcriptomics studies reported a larger pool of drought-responsive transcription factors than proteomics studies, which drive gene expression changes. Some of the identified stress-responsive proteins are possibly involved in protein synthesis, stability and turnover events, primary and secondary metabolism, cell growth processes, osmoregulation, protective functions against dehydration, plant defense, and ROS detoxification processes (Figure 2). Although this illustration is not exhaustive, it shows well-known drought-responsive genes/proteins previously identified in Arabidopsis and other plants, including cereals $[60,64,65,100]$. Furthermore, the identification of $\beta$-alanine betaine biosynthesis enzymes in the sorghum drought-responsive transcriptome $[88,89]$ also provides new insights into the possible functions of this solute in the crop. Beta-alanine betaine in known to accumulate in the stress-tolerant plant family Plumbaginaceae where it possibly serves as an alternative osmoprotectant to glycine betaine under salinity and hypoxic conditions [118-121]. However, more functional studies are required to validate these drought-responsive genes/proteins in sorghum. 


\section{Conclusions and Future Perspectives}

Plants, including sorghum respond to water deprivation through complex alterations in gene and protein expression, with concomitant changes in whole-plant physiology and metabolism. Comparative "omics" studies, using sorghum varieties with contrasting drought phenotypes, have broadened our knowledge of cellular processes that potentially contribute towards the inherent superior nature of some sorghum genotypes. For example, under well-watered conditions, drought-tolerant sorghum exhibits higher constitutive expression of genes associated with secondary metabolism and ROS detoxification-related pathways. In addition, upon exposure to limited water supply, these varieties show increased alternative splicing events, higher expression of transcriptional factors, and the enrichment of genes and proteins associated with transcription, translation, protein synthesis, and ROS detoxification processes. Such molecular changes possibly contribute towards the drought resilience of sorghum plants by increasing the pool of regulatory and stress-responsive genes/proteins, increasing the functional diversity of resultant protein isoforms, and generating effective protective mechanisms against oxidative damage of cell constituents.

In contrast, drought-sensitive sorghum reduces metabolic activity, and increases protein degradation under water stress possibly as energy saving mechanisms in support of cell processes that are critical for plant survival. Epicuticular wax biosynthetic genes were also highly expressed under water deficit, emphasizing the importance of wax deposition in retarding cuticular water loss, and its reciprocal effect on water conservation. In addition, sorghum root physiology and metabolism under drought has emerged as a dynamic research area that deserves further study.

Indeed, the sorghum transcriptomics and proteomics studies reviewed in the current paper have employed a broad spectrum of experimental systems, analytical methods, sorghum varieties, and water stress treatments. Collectively, however, trends in constitutive, and drought-induced expression of genes/proteins involved in signaling, transcription, protein synthesis, secondary metabolism, protein stability, cellular transport and ROS detoxification processes have emerged as potential targets for future functional validation studies.

Because drought stress affects almost every metabolic pathway and process, a difficulty arises in interpreting the datasets that have been produced from these experiments. In particular, how does one identify key genes/proteins that are central to the adaptive response from peripheral changes that are a consequence of the reduced water availability? Even the use of near-isogenic sorghum lines in such experiments may not easily resolve this impediment. Refining the approach to include kinetic experiments focusing on early events after onset of drought is a potential avenue to identifying the critical components in sorghum adaptation to drought. This could be used in combination with forward genetic screens (employing mutagenized seeds) to identify components that are constitutively expressed and not responsive to drought stress. These challenges need to be resolved prior to incorporation of selected targets in breeding programs to produce more drought-resilient crops.

In the meantime, vital clues of the sorghum response to drought stress can be assembled from comparison with other model species. A great deal of protein functional validation has been achieved using Arabidopsis loss-of-function mutants and transgenic overexpression plants. Of particular note is the drought-induced biosynthesis of ABA and downstream signaling. Perception of water deficits activates biosynthesis of ABA, which binds to its receptor complex PYR/PYL/RCAR (Pyrabactin Resistance 1/PYR1Like/Regulatory Component of ABA Receptors) [122,123] to inhibit protein phosphatase 2C (PP2C) activity. PP2C inhibition triggers autophosphorylation of subclass III sucrose non-fermenting-1 (SNF1)-related protein kinase 2 (SnRK2) proteins, which then phosphorylate numerous downstream target genes important in adaptation to drought. Sorghum orthologs of Arabidopsis genes can be identified via homology searches and a putative sorghum ABA signaling module constructed by incorporating gene expression profiling 
data from Genevestigator (https: / / genevestigator.com/, accessed on 8 July 2021) [124] or similar databases. Figure 3 presents an example of such an exercise showing the response of sorghum orthologs of the ABA signaling genes, together with the enzyme catalyzing the commitment step in the biosynthesis of ABA. The transcriptomic results show activation of ABA biosynthesis, suppression of ABA receptor protein genes, and activation of PP2C and SnRK2 kinase genes. Suppression of ABA receptor genes possibly indicates transcriptional signal termination after PP2C inhibition has been achieved, while up-regulation of PP2C transcription could be a mechanism to re-establish normal homeostasis after SnRK2 activation has been completed. Analyses such as this one could provide useful hypotheses that can be tested using specific target genes for validation. A similar approach can be used to target different aspects of sorghum drought stress adaptation, such as biosynthesis of osmoprotectants.

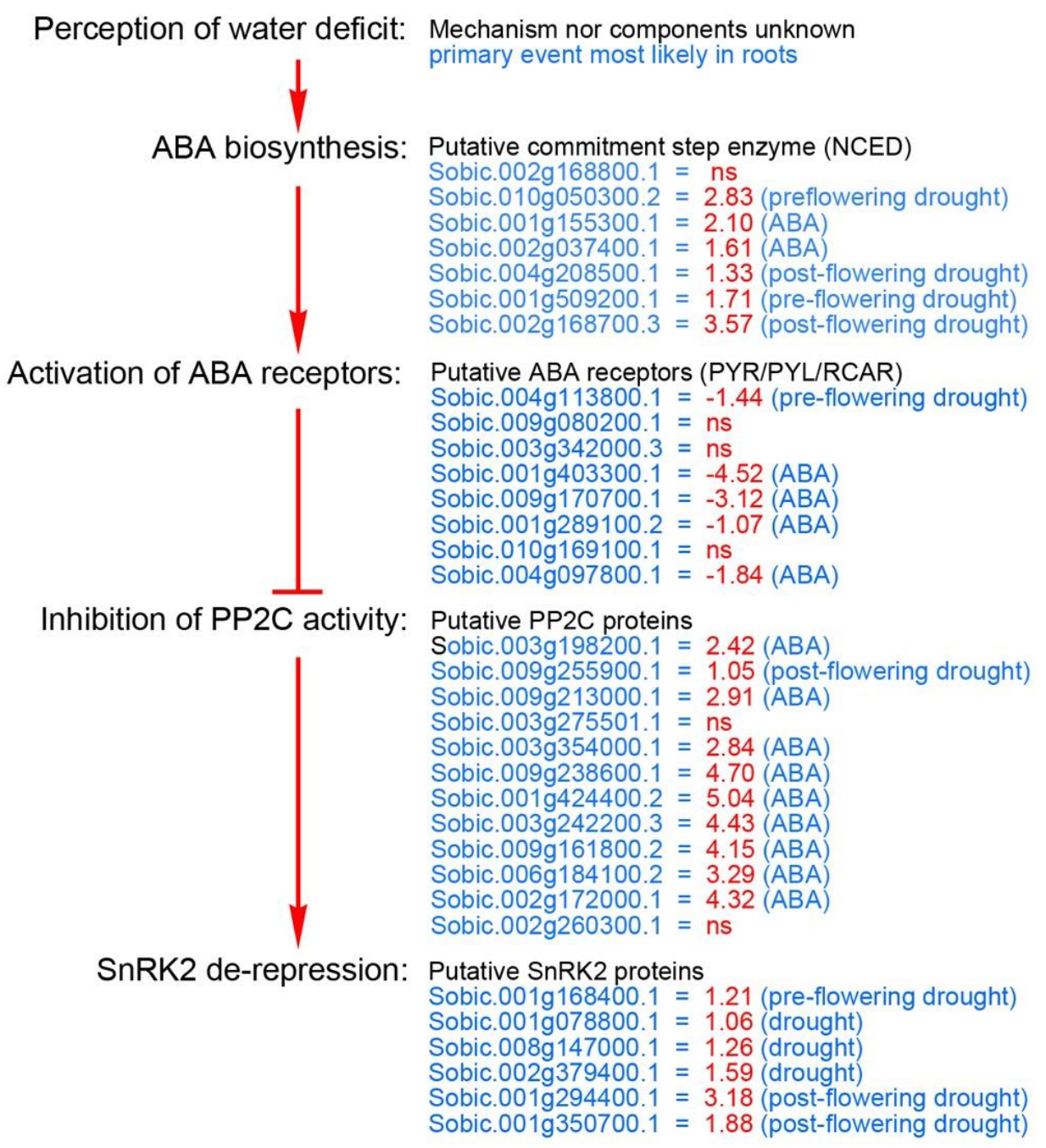

Figure 3. Transcriptomic responses of the putative sorghum ABA signaling module. Arabidopsis proteins were used with BLAST to search the Phytozome database for sorghum orthologs of (i) the commitment enzyme in the ABA biosynthesis pathway, (ii) the ABA receptor proteins-pyrabactin resistance (PYR)/PYR1-like (PYL)/regulatory component of ABA receptor (RCAR), (iii) the protein phosphatase 2C (PP2C) proteins, and (iv) the sucrose non-fermenting-1 (SNF1)-related protein kinase 2 (SnRK2). The response of each gene to drought or ABA was searched in the Genevestigator database [124] and the $\log 2$ ratio of treatment/control is provided in red font. The gene response data captured is from two field drought studies [19,74] and one laboratory-based ABA study [88]. Activation is denoted by a line with arrowhead, while protein inhibition is denoted by line ending with a T-junction. NCED, 9-cis-epoxycarotenoid dioxygenase; ns, no significant response. 
Author Contributions: Conceptualization, R.N.; writing-original draft preparation, R.N.; writingreview and editing, R.N., T.G., D.Z.H.S., S.C.; visualization, R.N, T.G., D.Z.H.S. and S.C. All authors have read and agreed to the published version of the manuscript.

Funding: This research received no external funding but forms part of the ongoing work in the R.N. group on sorghum responses to drought.

Institutional Review Board Statement: Not applicable.

Informed Consent Statement: Not applicable.

Conflicts of Interest: The authors declare no conflict of interest.

\section{References}

1. FAOSTATS. Food and Agriculture Data; Food and Agriculture Organisation: Rome, Italy, 2019; Available online: http://www.fao. org/faostat/en/\#data/QC (accessed on 11 February 2021).

2. National Research Council. Lost Crops of Africa: Grains; National Academy Press: Washington, DC, USA, 1996; Volume 1.

3. House, L.R. A Guide to Sorghum Breeding, 2nd ed.; International Crops Research Institute for the Semi-Arid Tropics: Patancheru, India, 1985.

4. Doggett, H. Sorghum, 2nd ed.; Longman Scientific \& Technical: Essex, UK, 1988.

5. Dahlberg, J.; Berenji, J.; Sikora, V.; Latkovic, D. Assessing sorghum [Sorghum bicolor (L) Moench] germplasm for new traits: Food, fuels \& unique uses. Maydica 2011, 56-1750, 85-92.

6. Wilkes, G. Strategies for Sustaining Crop. Germplasm Preservation, Enhancement, and Use; Consultative Group on International Agricultural Research, CGIAR Secretariat: Washington, DC, USA, 1992.

7. Kimber, C.T.; Dahlberg, J.A.; Kresovich, S. The gene pool of Sorghum bicolor and its improvement. In Genomics of the Saccharinae; Paterson, A.H., Ed.; Springer: New York, NY, USA, 2013; Volume 11, pp. 23-41.

8. Upadhyaya, H.D.; Sharma, S.; Dwivedi, S.L.; Singh, S.K. Sorghum genetics resources: Conservation and diversity assessment for enhanced utilization in sorghum improvement. In Genetics, Genomics and Breeding of Sorghum; Wang, H., Upadhyaya, H.D., Kole, C., Eds.; CRC Press: New York, NY, USA, 2014; pp. 28-55.

9. Upadhyaya, H.D.; Vetriventhan, M.; Asiri, A.M.; Azevedo, V.C.R.; Sharma, H.C.; Sharma, R.; Sharma, S.P.; Wang, Y.H. Multi-trait diverse germplasm sources from mini core collection for sorghum improvement. Agric. Basel 2019, 9, 121. [CrossRef]

10. Kumar, A.S.; Reddy, B.V.S.; Sharma, H.C.; Hash, C.T.; Rao, P.S.; Ramaiah, B.; Reddy, P.S. Recent advances in sorghum genetic enhancement research at ICRISAT. Am. J. Plant. Sci. 2011, 2, 589-600. [CrossRef]

11. Boyer, J.S. Plant productivity and environment. Science 1982, 218, 443-448. [CrossRef] [PubMed]

12. Mundia, C.W.; Secchi, S.; Akamani, K.; Wang, G. A regional comparison of factors affecting global sorghum production: The case of North America, Asia and Africa's Sahel. Sustainability 2019, 11, 2135. [CrossRef]

13. IPCC. Summary for Policymakers; Cambridge University Press: Cambridge, UK, 2007; pp. 7-22.

14. Nelson, G.C.; Rosegrant, M.; Koo, J.; Robertson, R.; Sulser, T.; Zhu, T.; Msangi, S.; Ringler, C.; Palazzo, A.; Batka, M.; et al. Climate Change. Impact on Agriculture and Costs of Adapation; International Food Policy Research Institute: Washington, DC, USA, 2009.

15. Clarke, J.M.; Karamanos, A.J.; Simpson, G.M. Case example of research progress in drought-stressed physiology. In Water Stress on Plants; Simpson, C.D., Ed.; Praeger Publishers: New York, NY, USA, 1981; pp. 140-199.

16. Rosenow, D.T.; Quisenberry, J.E.; Wendt, C.W.; Clark, L.E. Drought tolerant sorghum and cotton germplasm. Agr. Water Manag. 1983, 7, 207-222. [CrossRef]

17. Amelework, B.A.; Shimelis, H.A.; Tongoona, P.; Mengistu, F.; Laing, M.D.; Ayele, D.G. Sorghum production systems and constraints, and coping strategies under drought-prone agro-ecologies of Ethiopia. South Afr. J. Plant Soil 2016, 33, $207-217$. [CrossRef]

18. Burke, J.J.; Chen, J.; Burow, G.; Mechref, Y.; Rosenow, D.; Payton, P.; Xin, Z.; Hayes, C.M. Leaf dhurrin content is a quantitative measure of the level of pre- and postflowering drought tolerance in sorghum. Crop. Sci. 2013, 53, 1056-1065. [CrossRef]

19. Varoquaux, N.; Cole, B.; Gao, C.; Pierroz, G.; Baker, C.R.; Patel, D.; Madera, M.; Jeffers, T.; Hollingsworth, J.; Sievert, J.; et al. Transcriptomic analysis of field-droughted sorghum from seedling to maturity reveals biotic and metabolic responses. Proc. Natl. Acad. Sci. USA 2019, 116, 27124-27132. [CrossRef] [PubMed]

20. Borrell, A.K.; Hammer, G.L.; Douglas, A.C.L. Does maintaining green leaf area in sorghum improve yield under drought? I. Leaf growth and senescence. Crop. Sci. 2000, 40, 1026-1037. [CrossRef]

21. Thomas, H.; Howarth, C.J. Five ways to stay green. J. Exp. Bot. 2000, 51, 329-337. [CrossRef] [PubMed]

22. Sanchez, A.C.; Subudhi, P.K.; Rosenow, D.T.; Nguyen, H.T. Mapping QTLs associated with drought resistance in sorghum (Sorghum bicolor L. Moench). Plant Mol. Biol. 2002, 48, 713-726. [CrossRef]

23. Paterson, A.H.; Bowers, J.E.; Bruggmann, R.; Dubchak, I.; Grimwood, J.; Gundlach, H.; Haberer, G.; Hellsten, U.; Mitros, T.; Poliakov, A.; et al. The Sorghum bicolor genome and the diversification of grasses. Nature 2009, 457, 551-556. [CrossRef]

24. Goodstein, D.M.; Shu, S.Q.; Howson, R.; Neupane, R.; Hayes, R.D.; Fazo, J.; Mitros, T.; Dirks, W.; Hellsten, U.; Putnam, N.; et al. Phytozome: A comparative platform for green plant genomics. Nucleic Acids Res. 2012, 40, D1178-D1186. [CrossRef] 
25. Agarwala, R.; Barrett, T.; Beck, J.; Benson, D.A.; Bollin, C.; Bolton, E.; Bourexis, D.; Brister, J.R.; Bryant, S.H.; Canese, K.; et al. Database resources of the National Center for Biotechnology Information. Nucleic Acids Res. 2018, 46, D8-D13.

26. Sasaki, T.; Antonio, B.A. Plant genomics: Sorghum in sequence. Nature 2009, 457, 547-548. [CrossRef]

27. Edwards, D.; Batley, J. Plant genome sequencing: Applications for crop improvement. Plant Biotechnol. J. 2010, 8, 2-9. [CrossRef]

28. Bolger, M.E.; Weisshaar, B.; Scholz, U.; Stein, N.; Usadel, B.; Mayer, K.F.X. Plant genome sequencing-applications for crop improvement. Curr. Opin. Biotechnol. 2014, 26, 31-37. [CrossRef]

29. Mullet, J.E.; Klein, R.R.; Klein, P.E. Sorghum bicolor-an important species for comparative grass genomics and a source of beneficial genes for agriculture. Curr. Opin. Plant Biol. 2001, 5, 118-121. [CrossRef]

30. Paterson, A.H. The sorghum genome sequence: A core resource for Saccharinae genomics. In Genomics of the Saccharinae; Paterson, A.H., Ed.; Springer: New York, NY, USA, 2013; Volume 11, pp. 105-117.

31. Ware, D.H.; Jaiswal, P.J.; Ni, J.J.; Yap, I.; Pan, X.K.; Clark, K.Y.; Teytelman, L.; Schmidt, S.C.; Zhao, W.; Chang, K.; et al. Gramene, a tool for grass genomics. Plant Physiol. 2002, 130, 1606-1613. [CrossRef]

32. Valentin, G.; Abdel, T.; Gaetan, D.; Jean-Francois, D.; Matthieu, C.; Mathieu, R. GreenPhylDB v5: A comparative pangenomic database for plant genomes. Nucleic Acids Res. 2021, 49, D1464-D1471.

33. Spannagl, M.; Nussbaumer, T.; Bader, K.C.; Martis, M.M.; Seidel, M.; Kugler, K.G.; Gundlach, H.; Mayer, K.F.X. PGSB PlantsDB: Updates to the database framework for comparative plant genome research. Nucleic Acids Res. 2016, 44, D1141-D1147. [CrossRef]

34. Dong, Q.F.; Schlueter, S.D.; Brendel, V. PlantgDB, plant genome database and analysis tools. Nucleic Acids Res. 2004, 32, D354-D359. [CrossRef] [PubMed]

35. Tian, T.; You, Q.; Zhang, L.W.; Yi, X.; Yan, H.Y.; Xu, W.Y.; Su, Z. SorghumFDB: Sorghum functional genomics database with multidimensional network analysis. Database Oxf. 2016, 2016, baw099. [CrossRef]

36. Luo, H.; Zhao, W.M.; Wang, Y.Q.; Xia, Y.; Wu, X.Y.; Zhang, L.M.; Tang, B.X.; Zhu, J.W.; Fang, L.; Du, Z.L.; et al. SorGSD: A sorghum genome SNP database. Biotechnol. Biofuels 2016, 9, 6. [CrossRef]

37. Mochizuki, T.; Tanizawa, Y.; Fujisawa, T.; Ohta, T.; Nikoh, N.; Shimizu, T.; Toyoda, A.; Fujiyama, A.; Kurata, N.; Nagasaki, H.; et al. DNApod: DNA polymorphism annotation database from next-generation sequence read archives. PLoS ONE 2017, 2, e0172269. [CrossRef]

38. Yilmaz, A.; Nishiyama, M.Y.J.; Fuentes, B.G.; Souza, G.M.; Janies, D.; Gray, J.; Grotewold, E. GRASSIUS: A platform for comparative regulatory genomics across the grasses. Plant Physiol. 2009, 149, 171-180. [CrossRef]

39. Zhang, J.J.; Hao, Z.Q.; Yin, S.W.; Li, G.L. GreenCircRNA: A database for plant CircRNAs that act as miRNA decoys. Database Oxf. 2020, 2020, baaa039. [CrossRef]

40. Moriya, Y.; Itoh, M.; Okuda, S.; Yoshizawa, A.C.; Kanehisa, M. KAAS: An automatic genome annotation and pathway reconstruction server. Nucleic Acids Res. 2007, 35, W182-W185. [CrossRef]

41. Kozomara, A.; Griffiths-Jones, S. miRBase: Annotating high confidence microRNAs using deep sequencing data. Nucleic Acids Res. 2014, 42, D68-D73. [CrossRef]

42. Makita, Y.; Shimada, S.; Kawashima, M.; Kondou-Kuriyama, T.; Toyoda, T.; Matsui, M. Morokoshi: Transcriptome database in Sorghum bicolor. Plant Cell Physiol. 2015, 56, e6. [CrossRef]

43. Jin, J.; Tian, F.; Yang, D.-C.; Meng, Y.-Q.; Kong, L.; Luo, J.; Gao, G. PlantTFDB 4.0: Toward a central hub for transcription factors and regulatory interactions in plants. Nucleic Acids Res. 2016, 45, D1040-D1045. [CrossRef] [PubMed]

44. Li, J.R.; Liu, C.C.; Sun, C.H.; Chen, Y.T. Plant stress RNA-seq Nexus: A stress-specific transcriptome database in plant cells. BMC Genom. 2018, 19, 966. [CrossRef] [PubMed]

45. Dai, X.B.; Zhuang, Z.H.; Zhao, P.X.C. psRNAtarget: A plant small RNA target analysis server (2017 release). Nucleic Acids Res. 2018, 46, W49-W54. [CrossRef]

46. Gupta, N.; Singh, A.; Zahra, S.; Kumar, S. PtRFdb: A database for plant transfer RNA-derived fragments. Database Oxf. 2018, 2018, bay063. [CrossRef]

47. Wu, H.-J.; Ma, Y.-K.; Chen, T.; Wang, M.; Wang, X.-J. PsRobot: A web-based plant small RNA meta-analysis toolbox. Nucleic Acids Res. 2012, 49, W22-WW28. [CrossRef] [PubMed]

48. Stocks, M.B.; Mohorianu, I.; Beckers, M.; Paicu, C.; Moxon, S.; Thody, J.; Dalmay, T.; Moulton, V. The UEA sRNA Workbench (version 4.4): A comprehensive suite of tools for analyzing miRNAs and sRNAs. Bioinformatics 2018, 34, 3382-3384. [CrossRef]

49. Hooper, C.M.; Castleden, I.R.; Aryamanesh, N.; Jacoby, R.P.; Millar, A.H. Finding the subcellular location of barley, wheat, rice and maize proteins: The compendium of crop proteins with annotated locations (cropPAL). Plant Cell Physiol. 2016, 57, e9. [CrossRef]

50. Clemente, H.S.; Pont-Lezica, R.; Jamet, E. Bioinformatics as a tool for assessing the quality of sub-cellular proteomic strategies and inferring functions of proteins: Plant cell wall proteomics as a test case. Bioinform. Biol. Insights 2009, 3, 15-28. [CrossRef]

51. Artimo, P.; Jonnalagedda, M.; Arnold, K.; Baratin, D.; Csardi, G.; de Castro, E.; Duvaud, S.; Flegel, V.; Fortier, A.; Gasteiger, E.; et al. ExPASy: SIB bioinformatics resource portal. Nucleic Acids Res. 2012, 40, W597-W603. [CrossRef]

52. Bateman, A.; Martin, M.J.; Orchard, S.; Magrane, M.; Agivetova, R.; Ahmad, S.; Alpi, E.; Bowler-Barnett, E.H.; Britto, R.; Bursteinas, B.; et al. UniProt: The universal protein knowledgebase in 2021. Nucleic Acids Res. 2021, 49, D480-D489.

53. Tian, T.; Liu, Y.; Yan, H.Y.; You, Q.; Yi, X.; Du, Z.; Xu, W.Y.; Su, Z. AgriGo v2.0: A GO analysis toolkit for the agricultural community, 2017 update. Nucleic Acids Res. 2017, 45, W122-W129. [CrossRef]

54. Kanehisa, M.; Goto, S. KEGG: Kyoto encyclopedia of genes and genomes. Nucleic Acids Res. 2000, 28, 27-30. [CrossRef]

55. Taiz, L.; Zeiger, E. Plant Physiology, 4th ed.; Sinauer Associates Inc.: Sunderland, MA, USA, 2010. 
56. Molles, M.C., Jr. Ecology: Concepts and Applications, 8th ed.; McGraw-Hill Education: New York, NY, USA, 2019.

57. Levitt, J. Responses of Plants to Environmental Stresses, 2nd ed.; Academic Press: New York, NY, USA, 1980; Volume II.

58. Bray, E.A. Molecular responses to water deficit. Plant Physiol. 1993, 103, 1035-1040. [CrossRef]

59. Bray, E.A. Plant responses to water deficit. Trends Plant Sci. 1997, 2, 48-54. [CrossRef]

60. Xiong, L.; Zhu, J.K. Molecular and genetic aspects of plant responses to osmotic stress. Plant Cell Environ. 2002, 25, 131-139. [CrossRef]

61. Clarke, J.M.; Durley, R.C. The responses of plants to drought stress. In Water Stress on Plants; Simpson, G.M., Ed.; Praeger Publishers: New York, NY, USA, 1981; pp. 89-139.

62. Hale, M.G.; Orcutt, D.M.; Thompson, L.K. The Physiology of Plants Under Stress; Wiley: New York, NY, USA, 1987.

63. Farooq, M.; Wahid, A.; Kobayashi, N.; Fujita, D.; Basra, S.M.A. Plant drought stress: Effects, mechanisms and management. Agron. Sustain. Dev. 2009, 29, 185-212. [CrossRef]

64. Seki, M.; Kamei, A.; Yamaguchi-Shinozaki, K.; Shinozaki, K. Molecular responses to drought, salinity and frost: Common and different paths for plant protection. Curr. Opin. Biotechnol. 2003, 14, 194-199. [CrossRef]

65. Shinozaki, K.; Yamaguchi-Shinozaki, K. Molecular responses to drought and cold stress. Curr. Opin. Biotechnol. 1996, 7, 161-167. [CrossRef]

66. Davies, W.J.; Kudoyarova, G.; Hartung, W. Long-distance ABA signaling and its relation to other signaling pathways in the detection of soil drying and the mediation of the plant's response to drought. J. Plant Growth Regul. 2005, 24, 285-295. [CrossRef]

67. Amelework, B.; Shimelis, H.; Tongoona, P.; Laing, M. Physiological mechanisms of drought tolerance in sorghum, genetic basis and breeding methods: A review. Afr. J. Agric. Res. 2015, 10, 3029-3040.

68. Tari, I.; Laskay, G.; Takacs, Z.; Poor, P. Responses of sorghum to abiotic stresses: A review. J. Agron. Crop Sci. 2012, 199, 264-274. [CrossRef]

69. Blum, A. Sorghum physiology. In Physiology and Biotechnology Intergration for Plant Breeding; Nguyen, H., Blum, A., Eds.; Marcel Dekker, Inc.: New York, NY, USA, 2004; pp. 141-223.

70. Blum, A.; Arkin, G.F. Sorghum root-growth and water-use as affected by water-supply and growth duration. Field Crop. Res. 1984, 9, 131-142. [CrossRef]

71. Goche, T.; Shargie, N.G.; Cummins, I.; Brown, A.P.; Chivasa, S.; Ngara, R. Comparative physiological and root proteome analyses of two sorghum varieties responding to water limitation. Sci. Rep. 2020, 10, 11835. [CrossRef] [PubMed]

72. Ogbagaa, C.C.; Stepien, P.; Johnson, G.N. Sorghum (Sorghum bicolor) varieties adopt strongly contrasting strategies in response to drought. Physiol. Plant 2014, 152, 389-401. [CrossRef]

73. Johnson, S.M.; Lim, F.L.; Finkler, A.; Fromm, H.; Slabas, A.R.; Knight, M.R. Transcriptomic analysis of Sorghum bicolor responding to combined heat and drought stress. BMC Genom. 2014, 15, 456. [CrossRef]

74. Fracasso, A.; Trindade, L.M.; Amaducci, S. Drought stress tolerance strategies revealed by RNA-Seq in two sorghum genotypes with contrasting WUE. BMC Plant Biol. 2016, 16, 115. [CrossRef]

75. Ebercon, A.; Blum, A.; Jordan, W.R. A rapid colorimetric method for epicuticular wax content of sorghum leaves. Crop. Sci. 1977, 17, 179-180. [CrossRef]

76. Sanjari, S.; Shobbar, Z.-S.; Ghanati, F.; Afshari-Behbahanizadeh, S.; Farajpour, M.; Jokar, M.; Khazaei, A.; Shahbazi, M. Molecular, chemical, and physiological analyses of sorghum leaf wax under post-flowing drought stress. Plant Physiol. Biochem. 2021, 159, 383-391. [CrossRef]

77. Chaves, M.M.; Maroco, J.P.; Pereira, J.S. Understanding plant responses to drought-from genes to the whole plant. Funct. Plant Biol. 2003, 30, 239-264. [CrossRef]

78. Kitano, H. Systems biology: A brief overview. Science 2002, 295, 1662-1664. [CrossRef]

79. Korth, K.L. Genes and traits of interest for transgenic plants. In Plant Biotechnology and Genetics: Principles, Techniques, and Applications; Stewart, C.N., Jr., Ed.; John Wiley \& Sons: Hoboken, NJ, USA, 2008; pp. 193-216.

80. Cramer, G.R.; Urano, K.; Delrot, S.; Pezzotti, M.; Shinozaki, K. Effects of abiotic stress on plants: A systems biology perspective. BMC Plant Biol. 2011, 11, 163. [CrossRef]

81. Wang, Z.; Gerstein, M.; Snyder, M. RNA-Seq: A revolutionary tool for transcriptomics. Nat. Rev. Genet. 2009, 10, 57-63. [CrossRef]

82. Lowe, R.; Shirley, N.; Bleackley, M.; Dolan, S.; Shafee, T. Transcriptomics technologies. PLoS Comput. Biol. 2017, 13, e1005457. [CrossRef]

83. Szymanski, M.; Barciszewska, M.Z.; Zywicki, M.; Barciszewski, J. Noncoding RNA transcripts. J. Appl. Genet. 2003, 44, 1-19. [PubMed]

84. Guleria, P.; Mahajan, M.; Bhardwaj, J.; Yadav, S.K. Plant small RNAs: Biogenesis, mode of action and their roles in abiotic stresses. Genom. Proteom. Bioinform. 2011, 9, 183-199. [CrossRef]

85. Cheng, Y.; Weng, J.; Joshi, C.P.; Nguyen, H.T. Dehydration stress-induced changes in translatable RNAs in sorghum. Crop Sci. 1993, 33, 1397-1400. [CrossRef]

86. Wood, A.J.; Goldsbrough, P.B. Characterization and expression of dehydrins in water-stressed Sorghum bicolor. Physiol. Plant 1997, 99, 144-152. [CrossRef]

87. Buchanan, C.D.; Lim, S.; Salzman, R.A.; Kagiampakis, I.; Morishige, D.T.; Weers, B.D.; Klein, R.R.; Pratt, L.H.; Cordonnier-Pratt, M.M.; Klein, P.E.; et al. Sorghum bicolor's transcriptome response to dehydration, high salinity and ABA. Plant Mol. Biol. 2005, 58, 699-720. [CrossRef] [PubMed] 
88. Dugas, D.V.; Monaco, M.K.; Olson, A.; Klein, R.R.; Kumari, S.; Ware, D.; Klein, P.E. Functional annotation of the transcriptome of Sorghum bicolor in response to osmotic stress and abscisic acid. BMC Genom. 2011, 12, 514. [CrossRef]

89. Devnarain, N.; Crampton, B.G.; Olivier, N.; van der Westhuyzen, C.; Becker, J.V.W.; O' Kennedy, M.M. Transcriptomic analysis of a Sorghum bicolor landrace identifies a role for beta-alanine betaine biosynthesis in drought tolerance. S. Afr. J. Bot. 2019, 127, 244-255. [CrossRef]

90. Zhang, D.-F.; Zeng, T.-R.; Liu, X.-Y.; Gao, C.-X.; Li, Y.-X.; Li, C.-H.; Song, Y.-C.; Shi, Y.-S.; Wang, T.-Y.; Li, Y. Transcriptomic profiling of sorghum leaves and roots responsive to drought stress at the seedling stage. J. Inter. Agric. 2019, 18, 1980-1995. [CrossRef]

91. Abdel-Grany, S.E.; Ullah, F.; Ben-Hur, A.; Reddy, A.S.N. Transcriptome analysis of drought-resistant and drought-sensitive sorghum (Sorghum bicolor) genotypes in response to PEG-induced drought stress. Int. J. Mol. Sci. 2020, 21, 772. [CrossRef] [PubMed]

92. Azzouz-Olden, F.; Hunt, A.G.; Dinkins, R. Transcriptome analysis of drought-tolerant sorghum genotype SC56 in response to water stress reveals an oxidative stress defense strategy. Mol. Biol. Rep. 2020, 47, 3291-3303. [CrossRef]

93. Katiyar, A.; Smita, S.; Muthusamy, S.K.; Chinnusamy, V.; Pandey, D.M.; Bansal, K.C. Identification of novel drought-responsive microRNAs and trans-acting siRNAs from Sorghum bicolor (L.) Moench by high-throughput sequencing analysis. Front. Plant Sci. 2015, 6, 506. [CrossRef]

94. Hamza, N.B.; Sharma, N.; Tripathi, A.; Sanan-Mishra, N. MicroRNA expression profiles in response to drought stress in Sorghum bicolor. Gene Expr. Patterns 2016, 20, 88-98. [CrossRef]

95. Close, T.J. Dehydrins: Emergence of a biochemical role of a family of plant dehydration proteins. Physiol. Plant 1996, 97, 795-803. [CrossRef]

96. Campbell, S.A.; Close, T.J. Dehydrins: Genes, proteins, and associations with phenotypic traits. New Phytol. 1997, 137, 61-74. [CrossRef]

97. Monshausen, G.B.; Gilroy, S. The exploring root-root growth responses to local environmental conditions. Curr. Opin. Plant Biol. 2009, 12, 766-772. [CrossRef]

98. Mittler, R. Abiotic stress, the field environment and stress combination. Trends Plant Sci. 2006, 11, 15-19. [CrossRef]

99. Suzuki, N.; Rivero, R.M.; Shulaev, V.; Blumwald, E.; Mittler, R. Abiotic and biotic stress combinations. New Phytol. 2014, $203,32-43$. [CrossRef]

100. Wang, W.; Vinocur, B.; Altman, A. Plant responses to drought, salinity and extreme temperatures: Towards genetic engineering for stress tolerance. Planta 2003, 218, 1-14. [CrossRef] [PubMed]

101. Smirnoff, N. The role of active oxygen in the response of plants to water deficit and desiccation. New Phytol. 1993, 125, 27-58. [CrossRef] [PubMed]

102. Mittler, R. Oxidative stress, antioxidants and stress tolerance. Trends Plant Sci. 2002, 7, 405-410. [CrossRef]

103. Knight, H.; Knight, M.R. Abiotic stress signalling pathways: Specificity and cross-talk. Trends Plant Sci. 2001, 6, 262-267. [CrossRef]

104. Osmolovskaya, N.; Shumilina, J.; Kim, A.; Didio, A.; Grishina, T.; Bilova, T.; Keltsieva, O.A.; Zhukov, V.; Tikhonovich, I.; Tarakhovskaya, E.; et al. Methodology of drought stress research: Experimental setup and physiological characterization. Int. J. Mol. Sci. 2018, 19, 4089. [CrossRef]

105. Mastrangelo, A.M.; Marone, D.; Laido, G.; De Leonardis, A.M.; De Vita, P. Alternative splicing: Enhancing ability to cope with stress via transcriptome plasticity. Plant Sci. 2012, 185, 40-49. [CrossRef] [PubMed]

106. Syed, N.H.; Kalyna, M.; Marquez, Y.; Barta, A.; Brown, J.W.S. Alternative splicing in plants-coming of age. Trends Plant Sci. 2012, 17, 616-623. [CrossRef]

107. Chaudhary, S.; Khokhar, W.; Jabre, I.; Reddy, A.S.N.; Byrne, L.J.; Wilson, C.M.; Syed, N.H. Alternative splicing and protein diversity: Plants versus animals. Front. Plant Sci. 2019, 10, 708. [CrossRef]

108. Blackstock, W.P.; Weir, M.P. Proteomics: Quantitative and physical mapping of cellular proteins. Trends Biotechnol. 1999, 17, 121-127. [CrossRef]

109. Pandey, A.; Mann, M. Proteomics to study genes and genomes. Nature 2000, 405, 837-846. [CrossRef]

110. Monteoliva, L.; Albar, J.P. Differential proteomics: An overview of gel and non-gel based approaches. Brief. Funct. Genomic. Proteom. 2004, 3, 220-239. [CrossRef] [PubMed]

111. Barkla, B.J.; Vera-Estrella, R.; Pantoja, O. Progress and challenges for abiotic stress proteomics of crop plants. Proteomics 2013, 13, 1801-1815. [CrossRef]

112. Kosova, K.; Vitamvas, P.; Prasil, I.T.; Renaut, J. Plant proteome changes under abiotic stress-contribution of proteomics studies to understanding plant stress response. J. Proteom. 2011, 74, 1301-1322. [CrossRef] [PubMed]

113. Ahmad, P.; Latef, A.A.H.A.; Rasool, S.; Akram, N.A.; Ashraf, M.; Gucel, S. Role of proteomics in crop stress tolerance. Front. Plant Sci. 2016, 7, 1336. [CrossRef] [PubMed]

114. Kosova, K.; Vitamvas, P.; Urban, M.O.; Prasil, I.T.; Renaut, J. Plant abiotic stress proteomics: The major factors determining alterations in cellular proteome. Front. Plant Sci. 2018, 9, 122. [CrossRef] [PubMed]

115. Jedmowski, C.; Ashoub, A.; Beckhaus, T.; Berberich, T.; Karas, M.; Bruggemann, W. Comparative analysis of Sorghum bicolor proteome in response to drought stress and following recovery. Int. J. Proteom. 2014, 2014, 395905. [CrossRef] [PubMed]

116. Li, H.; Li, Y.; Ke, Q.; Kwak, S.-S.; Zhang, S.; Deng, X. Physiological and differential proteomic analyses of imitation drought stress response in Sorghum bicolor root at the seedling stage. Int. J. Mol. Sci. 2020, 21, 9174. [CrossRef] [PubMed] 
117. Fadoul, H.E.; El Siddig, M.A.; Abdalla, A.W.H.; El Hussein, A.A. Physiological and proteomic analysis of two contrasting Sorghum bicolor genotypes in response to drought stress. Aust. J. Crop Sci. 2018, 12, 1543-1551. [CrossRef]

118. Rhodes, D.; Hanson, A.D. Quaternary ammonium and tertiary sulfonium compounds in higher-plants. Annu. Rev. Plant Physiol. Plant Mol. Biol. 1993, 44, 357-384. [CrossRef]

119. Hanson, A.D.; Rathinasabapathi, B.; Rivoal, J.; Burnet, M.; Dillon, M.O.; Gage, D.A. Osmoprotective compounds in the Plumbaginaceae-a natural experiment in metabolic engineering of stress tolerance. Proc. Natl. Acad. Sci. USA 1994, 91, 306-310. [CrossRef] [PubMed]

120. Rathinasabapathi, B.; Sigua, C.; Ho, J.; Gage, D.A. Osmoprotectant beta-alanine betaine synthesis in the Plumbaginaceae: Sadenosyl-L-methionine dependent N-methylation of beta-alanine to its betaine is via $N$-methyl and $N, N$-dimethyl beta-alanines. Physiol. Plant 2000, 109, 225-231. [CrossRef]

121. Rathinasabapathi, B.; Fouad, W.M.; Sigua, C.A. beta-alanine betaine synthesis in the Plumbaginaceae. Purification and characterization of a trifunctional, S-adenosyl-L-methionine-dependent N-methyltransferase from Limonium latifolium leaves. Plant Physiol. 2001, 126, 1241-1249. [CrossRef] [PubMed]

122. Ma, Y.; Szostkiewicz, I.; Korte, A.; Moes, D.; Yang, Y.; Christmann, A.; Grill, E. Regulators of PP2C phosphatase activity function as abscisic acid sensors. Science 2009, 324, 1064-1068. [CrossRef] [PubMed]

123. Park, S.Y.; Fung, P.; Nishimura, N.; Jensen, D.R.; Fujii, H.; Zhao, Y.; Lumba, S.; Santiago, J.; Rodrigues, A.; Chow, T.F.F.; et al. Abscisic acid inhibits type 2C protein phosphatases via the PYR/PYL family of START proteins. Science 2009, 324, $1068-1071$. [CrossRef]

124. Hruz, T.; Laule, O.; Szabo, G.; Wessendorp, F.; Bleuler, S.; Oertle, L.; Widmayer, P.; Gruissem, W.; Zimmermann, P. GENEVESTIGATOR V3: A reference expression database for the meta-analysis of transcriptomes. Adv. Bioinform. $2008,2008,420747$. [CrossRef] 